\title{
6. Sound Serials: Media Contingency in the 1930 s
}

\begin{abstract}
Chapter 6 traces the impact of radio and television on the serials' mode of address, as the golden era of serials in the mid-1930s and early $1940 \mathrm{~s}$ coincided with the heyday of radio and the discursive consolidation of television as a broadcast medium in the United States. Film serials embraced the narrative forms and modes of address of radio and television and simultaneously reactivated possibilities offered by these media that were discursively negated at the time, for instance the use of television for point-to-point communication. In showcasing these options, serials not only reinstated full contingency at the historical moment of its curtailing, they also extended their own array of options of storytelling, managing a variety of anecdotes and adopted forms to exhibit and juxtapose multiple modes of address.
\end{abstract}

Keywords: film serials, history of television, history of radio, Gene Autry, transmedia, convergence culture

In the 1930s, serials found themselves entangled in a network of multifarious established and emerging media to an unprecedented extent. Radio had become an established mass medium, sound film was fully consolidated, newspaper comic strips were experiencing their heyday, and television was looming large on the horizon. In fact, the 'golden era' of film serials, which Higgins locates between 1936-1946 (2016: 98), coincides with the heyday of radio from 1937-1946 (Hilmes 1997: 184) as well as with the conceptual consolidation — although not yet the dissemination — of television in the mid-1930s (Sewell 2014: 44). At the time, serials picked up on characters and narratives from the popular daily 'funnies', which often already sported their own radio serials. Many serials referenced a specific source text in another medium, for instance AcE Drummond (Universal, 1936) and RADIO

Brasch, I., Film Serials and the American Cinema, 1910-1940: Operational Detection, Amsterdam University Press, 2018.

DOI: 10.5117/9789462986527/CHo6 
PAtrol (Universal, 1937), both of which begin each episode with a plot recap that visually resembles a comic strip. Additionally, a vast number of serials portray the multiplicity of media technologies that existed or were imagined at the time. Especially radio and television contraptions appear in multifarious forms. As chapter three has shown, the presentational address of serials accommodates their embracing of cross-media content and their showcasing of communication technologies. This mode of address, however, remains by no means fixed across the decades. Rather than examining the relations between the incarnations of a story in comics, radio, and film serials - which would also warrant interesting analyses-I will focus on the film serials themselves and on their negotiations of radio and television in order to show how the presentational mode of address allowed for a negotiation of media change and was itself transformed as a result. Instead of aiming to represent radio and television as conceptually consolidated media, film serials presented and demonstrated varying options of what radio and television could be.

Film serials expose radio and television as discursively constructed rather than technologically determined. In this context, it is important to recall Niklas Luhmann's distinction between medium and form. As Luhmann and scholars following in his footsteps have shown, a medium is an amalgamation of options, some of which temporarily converge into more concrete forms (Luhmann 1997: 198; cf. Krämer 1998: 560). Medium and form determine each other in the sense that the medium enables the existence of individual forms, but the medium itself can also only be apprehended through these forms (Esposito 2004: 11-12). Sound film, for instance, is a medium that is embedded in cinema as an institution, and film serials are forms among others, such as classical Hollywood films, comedy shorts, or newsreels. ${ }^{1}$ Sound film as a medium can only be apprehended in the form of individual films. More generally, media themselves are invisible, but they enable the actualization of forms, which in turn perpetually renew the contingent options that make up the medium. In short, 'medium and form reciprocally determine each other' (Krämer 1998: 56o, my translation). Importantly, every medium has the capacity to allow for a variety of forms. As Elena Esposito highlights, 'media are only potentialities, and their fundamental function is to make contingent something that was formerly

1 I am particularly considering sound film as the medium, because if a medium, according to Luhmann, describes a number of contingencies, the contingency of sound film is different from the contingency of silent film, first and foremost because the former includes all the options offered by synchronized sound technologies. 
indispensable' (2004: 12). ${ }^{2}$ In this context, the seeming consolidation of media in the 1930s was really a reduction of options, as discursive practices including legislation, censorship, and progressivist attempts at reform established some forms as a norm and marginalized others. Although they were similarly impacted by these discursively constructed restrictions, film serials, themselves a marginalized form, were discernibly reluctant to participate in the reduction of possibilities, but they reactivated options for a variety of media instead. Serials took seriously the idea that film, radio, and television are not rival media aiming to replace one another but clusters of contingencies that mutually impact each other-both as abstract ideas and in their existing forms. By visualizing and juxtaposing anecdotal examples of possible appropriations of technology, for instance amateur radio broadcasting and point-to-point radio communication, film serials reactivated a contingency that was obscured in the wake of media consolidation and the definition of certain forms as a norm. Serials formulated their own, alternative imaginations of contemporary media technologies and their uses and thereby made the contingent nature of a seemingly consolidated media landscape visible.

The consolidation or discursive reduction of forms, content, and the possible uses of radio and television resulted from negotiations among technicians, journalists, legislators, and other agents within a contested field of power relations (Hilmes 1997: xvi-xvii; Sewell 2014: 8-12; cf. Telotte 1999:3). In Michele Hilmes' view, radio discourse was a 'conflicting, tension-ridden site of the ruthless exercise of cultural hegemony, often demonstrating in its very effort to control the power and diversity of the alternative popular constructions that oppose and resist it' (1997: xvii). Television very much shared radio's discourse, as its 'seemingly stable cultural construction was in fact the product of a great deal of discursive work that remodeled conceptions of the medium's nature and uses to suit the demands of the moment, ultimately conforming television to the norms of sound broadcasting' (Sewell 2014: 9). As poverty-row productions, film serials posed no threat to cultural hegemony, which allowed them to innocuously re-open the discursive field. They anecdotally portrayed a variety of alternative uses of radio and television technologies, and they juxtaposed them in fictional settings that escaped the power struggles dominating the earlier discursive consolidation of these media. These cinematic creations of radio and television in turn impacted the serials' understanding of what film itself is or could be.

2 Luhmann himself writes that forms can be considered selections within the realm of a medium (in German: 'Formen als Selektion im Bereich eines Mediums') (1997: 89). 
Film serials thus bear evidence of the impact that media change can have on individual forms, such as the film serial, and on the filmic medium more generally. Reflecting on media change in his introduction to Convergence Culture, Henry Jenkins debunks the myth that new media threaten established ones: 'printed words did not kill spoken words. Cinema did not kill theater. Television did not kill radio. Each old medium was forced to coexist with the emerging media. [...]. Old media are not being replaced. Rather, their functions and status are shifted by the introduction of new technologies' (2006:14). The economic organization of the entertainment business itself supports a model of media change according to which coexistent media refashion themselves instead of replacing each other. In the $1930 \mathrm{~s}$ and afterwards, seemingly rivaling media were already pooled in larger business operations, which did not generate their profits predominantly from film production. As Paul Young explains,

the belief that, during times such as the inception of broadcast TV, the film industry feared media competitors would destroy the cinema, stems from the misguided assumption that the main business of Hollywood studios was and is the production of films, when exhibition, distribution [...], and cross-marketing (of tie-in toys and the like) have historically represented Hollywood's bottom line. (2006: xvii) ${ }^{3}$

Nevertheless, the businesses running studio-era Hollywood were networks composed of individual agents, whose occupations were restricted to one of a business's multiple branches. However much the integration of multiple media into unified corporations diminished the threats that radio, film, and television posed to each other, people engaged in film production as well as local cinema owners feared the eventual migration of audiences. In 1925, for instance, when film serials attracted fewer viewers than during their first heyday in the 1910s, an editorial in the Exhibitor's Trade Review held radio responsible for increasingly unstable box-office returns and argued that film serials could regularize attendance just like serial novels ensured a continuous popularity of story magazines (Exhibitor's Trade Review, 1925c). As filmmakers responded to such or similar legitimate or

3 Young adds that Janet Wasko, Michele Hilmes, and Christopher Anderson debunked the myth that radio killed film (2006: xvii-xviii). Wasko outlines the business cooperation that informed the dissemination and commercialization of early sound film, radio, and television (1994: 8-14). For a consideration of the relations between Hollywood filmmaking and radio, also see Hilmes, 1990. 
misperceived confrontations, coexisting media reciprocally fostered each other's transformation.

Film serials renegotiated their mode of address in the 1930s according to the real and imagined audience addresses of radio and television. As I will show, serials openly negotiated the affordances of their coexisting media and they juxtaposed their respective modes of address. Young points to such different modes of address and argues that

radio, $\mathrm{TV}$, and digital media texts have depended on models of address and reception that differ in at least three profound ways from the classical cinematic model: (1) the possibility of media-enabled social exchange; (2) "live" transmission; and (3) private consumption in the home. [...] Hollywood's on-screen fantasies about these media during their incipient phases return obsessively to these distinctions between film and home-media reception with equal parts denial of their pleasures and envy at the cinema's technological incapacity to replicate them. (2006: xxiii)

Film serials, I argue, displayed a similar fascination with the modes of address of other media, but their non-compliance with the rulebook of classical Hollywood cinema enabled them to redefine their own modes of address accordingly. Instead of practicing denial and envy, film serials took up techniques of storytelling and visual imagery from other media and they diegetically incorporated other media in order to capitalize on their modes of address. To return once more to the distinction of media and forms, film serials portrayed radio, for instance, as a medium through its forms, such as a musical feature or sentences communicated through radio. In such instances, film serials themselves acted as media that combined the forms of another medium such as radio (cf. Esposito 2004: 11). ${ }^{4}$ They engaged in a negotiation of different media and their forms and

4 Film serials can act as media because film itself is a loose medium. Esposito describes this complication as the recursive character of the medium/form distinction: 'The looser the medium, the more abstract the forms impressed in it can be. This abstractness can be amplified by the recursivity of the distinction medium/form; the elements constituting the medium can be themselves forms impressed in a different medium, and the forms can act as media for the imposition of other forms. The sentences of spoken language, for instance, can be the elements used in writing (another medium) to produce different combinations (forms)' (2004: 11). Importantly, the distinction between medium and form is always ascribed by an observer. Thus, 'what is a medium from one perspective can always become a form when viewed from another perspective' (Krämer 1998: 560, my translation). 
simultaneously exhibited and transformed themselves both as a medium and as a form. ${ }^{5}$

Due to the comparative bluntness of their presentational mode of storytelling, serials of the 1930s not only transformed their mode of address in a negotiation of radio and television, but they simultaneously staged this negotiation. As the first part of this chapter will demonstrate, Mascot's 1935 serial The PHANTOM EMPIRE pits the multiple modes of address enabled by film and radio against each other, and it foregrounds the interconnections between businesses engaging in the production of media content. Moreover, by combining anecdotes of numerous forms in one film serial and thereby placing them in one shared context, THE PHANTOM EMPIRE offers a glimpse at how media convergence could work outside of the confines of the film screen. In other terms, this particular serial outlines aspects of what Henry Jenkins has famously identified as media convergence. For Jenkins, convergence serves as an umbrella term that describes the circulation of the same or related content across multiple media, which consumers access through the various technologies that have emerged in the digital era, from cell phones to computers and video game consoles. These digital means of dissemination, moreover, enable active viewers to communicate with other fans on online platforms that producers of media content can similarly access. As a result, audiences exercise an unprecedented influence on media content, from which producers can profit (Jenkins 2006: 3, 15-16; see also Jenkins, Ford, \& Green 2013). Obviously, the analog media culture of the 1930s offered fewer means of dissemination and only limited channels for fan communication. Nevertheless, media content did travel from newspapers to cinema to radio at the time. Despite lacking the means to voice their responses in online forums, consumers were 'encouraged to seek out new information and make connections among dispersed media content' (Jenkins 2006: 3). My use of Jenkins' terminology will be restricted to the flow of content across media platforms and the readers' activity of correlating a story's or a brands' multiple variants. ThE PHANTOM EMPIRE envisions and demonstrates visually and narratively how 'in the world of media convergence, every story gets told, every brand gets sold, and every consumer gets courted across multiple media platforms' (p. 3). The serial

5 Thus, in a sense, film serials are practicing hypermediacy as defined by Bolter and Grusin: 'In digital technology, as often in the earlier history of Western representation, hypermediacy expresses itself as multiplicity. [...] In every manifestation, hypermediacy makes us aware of the medium or media and (in sometimes subtle and sometimes obvious ways) reminds us of our desire for immediacy' (1999: 33-34). 
exemplifies that, via the travelling of narrative content from one medium to another, seemingly competing media could interact in a larger, shared popular-cultural field. In a sense, the serial recreates on screen what Jenkins refers to as 'flow':

by convergence, I mean the flow of content across multiple media platforms, the cooperation between multiple media industries, and the migratory behavior of media audiences who will go almost anywhere in search of the kinds of entertainment experiences they want. Convergence is a word that manages to describe technological, industrial, cultural, and social changes. (pp. 2-3)

As I will show, The Phantom Empire on the one hand addressed the integration of multiple media into larger firms through the star figure of Gene Autry and on the other hand combined elements of radio, television, and cinema on screen.

In a second step, beginning with The Phantom EmpIRE but extending my argument to other sound serials, I will show how film serials reimagined radio and television in terms of earlier ideas of their usage as communications technologies rather than as unidirectional mass media. In fact, serials repeatedly foregrounded, questioned, and at times reaffirmed radio, television, and cinema's own unidirectional address. Serials reactivated the contingent spectrum of forms and they exercised a negotiation of multiple appropriations of these technologies and of their modes of address. These negotiations predominantly took place in relation to liveness as one quality that sound film, in contrast to radio and television, could not offer at the time. As I will show, serials adopted the notion of liveness by acting as media and taking up live forms from other media, that is, they showcased liveness rather than being live themselves.

\section{The Phantom Empire and Media Convergence}

The Phantom Empire is a 1935 science-fiction-Western-musical ${ }^{6}$ by Mascot, which according to Scott Higgins 'is part of a rich tradition that thrived at the very margins of studio-era Hollywood: a tradition of creative

6 The Phantom Empire is a particularly colorful case of genre-mixing. Nevertheless, the combination of genre markers, especially from disaster and horror film, the Western, and the musical is typical of late silent- and early sound-era science fiction film (Telotte 1999: 16). In 
ridiculousness, visual brio, and distinctively outlandish storytelling' (2016: 2). Indeed, the serial's own pressbook describes it as 'the weirdest story ever told'. ' It concerns radio star Gene Autry (in person), who lives on 'Radio Ranch', from where he airs a daily radio show with the help of his band and two children, Frankie and Betsy Baxter (Frankie Darro and Betsy King Ross). Twenty thousand feet underneath their ranch thrives a secret, technologically advanced society led by Queen Tika (Dorothy Christie), which is protected on the surface level by a mounted group called the 'thunder riders'. Queen Tika orders the thunder riders to dispose of Autry because his presence on the ranch invites too many 'surface people' to the area, who might find the secret entrance to Murania, the underground city. Meanwhile, a group of scientists also aims to murder Autry in order to find Murania and harvest its natural resources without interference. Consequently, the serial presents a wild goose chase for Autry, whose sole ambition again and again is to return to Radio Ranch in time for his radio broadcast.

The PhANTOM EMPIRE's negotiation of radio takes place against the backdrop of an economic context in which film studios increasingly became one branch of large corporations. Crossing media boundaries, Autry embodies the connection of multiple media and their businesses at the time. His status as recording, radio, and film star, and the inclusion of his cowboy songs in the serial highlighted the consolidation of businesses that enabled the production of The Phantom EmPIRE. Autry had emerged as a recording artist, singing cowboy songs for phonograph records that were marketed through mail-order catalogues, particularly Sears, to primarily rural homes (Stanfield 2002: 61). At a time when the flourishing of public broadcasting threatened the record business, record companies recruited talents like Autry to record songs for rural markets (pp. 52-53; cf. Lenthall 2007: 1112). Autry migrated to radio in 1928, when his morning show Conqueror

addition to The Phantom Empire, Ace Drummond (Universal, 1936) also features a singing protagonist.

7 In fact, 'the weirdest stories ever told' is a slogan that appeared on the covers of some issues of the pulp magazine Dime Mystery in the mid-1930s (Jones 1975: 15). Beginning in the 1920s, the attribute 'weird' was used for fiction with plots of outlandish horror that appeared for instance in the pulp magazine Weird Tales, which Everett and Shanks describe as 'nonrealist', 'extra-mainstream', 'speculative fiction' (Everett \& Shanks 2015: ix; see also Sorensen). Films of a similar quality were termed 'weirdies' and featured, as Henry Myers wrote in 1945, 'supposedly preternatural terrors such as were-wolves and vampires, and supposedly pseudo-scientific terrors such as mad scientists and inventors'. Particularly during the Depression, he argues, 'weirdies' caused both horror and laughter among audiences (Myers 1945: 20). Thanks to Frank Krutnik for pointing out the meaning of weirdness in this context to me. 
Record Time premiered on Sears' radio station WLS (World's Largest Store), a station similarly geared towards rural Mid-Westerners and Southerners. Additionally, he had a featured spot on The National Barn Dance, a variety show performed in front of a live audience and broadcast through the radio channel. In 1932, NBC picked it up and aired it nationally on Saturday nights (Stanfield 2002: 66-69). ${ }^{8}$

When The Phantom Empire was released, Autry had a record contract with the American Record Company, a firm owned by Herbert J. Yates, who designed Autry's career in recording, film, and radio. In 1935, Yates combined the independent studios Mascot, Liberty, Majestic, Chesterfield, and Monogram into Republic Pictures, thus also taking over Gene Autry's film contract from Mascot. ${ }^{9}$ As Peter Stanfield summarizes, 'Autry, then, was a key link in a chain that held Yates's various media investments together. Therefore, it is not surprising that Autry's film "character" is often acutely self-reflexive, often appearing within the diegesis as a recording and radio star' (2002: 84). The Phantom EmpIRE highlighted the advantages of a consolidation of various media for the fans, offering moving images of an idol they knew from radio. The serial's audience was composed of viewers who may also have tuned in to Autry's radio appearances, listened to his phonograph records, or ordered products that Autry advertised in the Sears catalog. Audiences were thus able to choose the media platform on which to experience the entertainment he offered. However, by casting the broadcast from Radio Ranch as hand-made by amateurs in America's cowboy heartland, THE PHANTOM EMPIRE not only reduced a possible threat posed by scientific advancement (cf. Miller 2009: 72), it also obscured the more pragmatic sources of mass media production. Moreover, the serial obfuscated the commercial interest behind its production - at a time when large amounts of radio content, especially day time serials but also nighttime variety shows, were in fact produced by advertising agencies who bought programming time for specific advertisers (Hilmes 1997: 118-21).

This obfuscation took place at a curious time: one year prior to the release of The Phantom Empire, the 1934 Communications Act terminated a reform movement that had emerged in opposition to radio's exclusively commercial use, to its economic and ideological concretion, and to monopolization. The medium's commercialization had been affirmed in the Radio Act of 1927, in which the government had regulated the allocation of frequencies and had

8 NBC's Blue Network was affiliated with WLS.

9 Autry was to appear in a number of Republic Westerns afterwards, but he did not make any film serials for Republic. 
officially endorsed a commercial, advertisement-based broadcasting system. It was in the wake of the Radio Act that the first national broadcasting stations were formed: NBC and CBS (Lenthall 2007: 11-12; McChesney 1993: 5). Between these legislations there was a seven-year period of both successful national radio shows and reform attempts. The Phantom EMPIRE thus envisioned a consolidation of media businesses that just recently had been heavily contested. This historical context in part explains the serial's paradoxical combination of an open embrace of media consolidation and the success of national radio that Autry symbolizes and its simultaneous presentation of Autry's diegetic radio show as a DIY production from the prairie.

In the early 1930s, business consolidation was fostered by overlaps in the technologies behind individual branches of mass media: the record business, radio, and sound film were all reproducing sound in one way or another (Sklar 1994: 156). ${ }^{10}$ In fact, Republic was a small company in comparison to the vertically integrated major studios (see chapter 3 of this volume). Nevertheless, The Phantom Empire's showcasing of Autry points to a larger trend of American film studios to merge companies into larger corporations. This process of unification and the resulting shift in the media landscape resembles, though on a smaller scale, aspects of what Jenkins describes as media convergence in the digital era. He explains that since the end of the twentieth century, narrative content has traveled easily and economically from the cinema screen to computer gaming because both are based on digital technologies to create special effects and high resolution (Jenkins 2006: 104). The first decade of sound film production saw a comparable appropriation of sound recording technology in various media and a resulting consolidation of business efforts (Uricchio 2008: 289; Wasko 1994: 8-14).

As mentioned earlier, the story world of The PHANTOM EMPIRE is limited to this particular film serial. ${ }^{11}$ On screen, however, the serial demonstrates

10 In order to access sound technologies, film studios teamed up with companies outside the film industry. They engaged in larger financial enterprises than before, buying other companies or being bought. Robert Sklar takes Warner Bros. and RKO as examples: 'The talkie revolution immediately forced the moguls into a new realm of industrial and financial enterprise. Sound, first of all, came from outside the industry: Warner Bros. got its Vitaphone sound system from Western Electric, a subsidiary of American Telephone and Telegraph. Radio Corporation of America put a sound system on the market and took over control of a studio and an exhibition company, merging them into a new firm, RKO' (1994:156). The result was the emergence of 'giant communications corporations' (p. 157).

11 The Phantom Empire did offer a comic strip, which exhibitors could order from the studio and give to their local newspapers. Exemplary comic panels were printed in the pressbook; the entire strip contained six strips of four panels each. 
how its narrative could cross over into radio by dividing the action into the portrayed world of radio production on the one hand, and a play-within-aplay in Autry's diegetic radio show on the other. The camera-eye penetrates both of these spaces, showing Autry's performed songs and his radio show's narrative serial as live-action events. The serial embraces the presentational address of earlier silent- and sound-era serials, which tend to display their narratives rather than immerse their viewers, but it adds a layer of media self-reflexivity by assembling a collage of anecdotes that relentlessly cross the threshold between the 'real' story and the diegetic radio show. Characters and anecdotal plot elements frequently travel from one narrative layer to another, blurring the lines and highlighting the existence of those lines at the same time - for instance when Tom Baxter, Autry's business partner on Radio Ranch, is shot in the live-action radio serial but, as it turns out, has truly been fatally wounded (episode 2 , 'The Thunder Riders'). Similarly, the ranch children's mounted adventure club appears both in the radio serial and on Radio Ranch. The PHAntom Empire thus places its narrative on the threshold between its depictions in the film serial and in the radio serial told within its diegetic radio show. Instead of presenting us with a narrative world that develops across numerous media platforms - as would be typical of media convergence-THE PHANTOM EMPIRE takes a meta-perspective and portrays convergence culture while its own story world is confined to its twelve episodes on the film screen. The serial assembles narrative elements and modes of address from radio and, later on, television and transforms them into anecdotes that can be assembled and juxtaposed on screen. The serial thereby displays how narration works both in the film serial and on radio, and it demonstrates how these media can or could work in concert.

The serial's narrative exemplifies the flow of content across media platforms, for example, when Queen Tika follows Autry's broadcast on her omnipresent surveillance television, on which she continues to monitor the proceedings on Radio Ranch after the radio show's air time - in fact adding another medial layer to the mix. The children Frankie and Betsy propose another form of media engagement: they invite the implied radio listeners to visit the ranch and to join their thunder riders club, and they suggest they should make their own thunder rider outfits. In this instance, THE PHANTOM EMPIRE mirrors a form of participatory reception that the film serial similarly encourages its non-diegetic audience to adopt. Its pressbook encourages local theaters to form clubs, to distribute paper thunder riders' masks, and to show slides before each week's screenings with a special message from the club president, Frankie Darro. At the time, such clubs often formed around particular serials, and they were part of a culture in 
which children reenacted their favorite plots in their free time (Higgins 2016). Such clubs confirm that participatory culture has its roots in practices that have occurred just below the radar of the media industry throughout the twentieth century' (Jenkins 2006: 133). In the present context, THE Phantom Empire quite explicitly uses stunt actress Betsy King Ross as a means to extend this invitation to play to girls in the audience. ${ }^{12}$

The formation of a thunder riders club among The Phantom EMPIRE's child viewers unleashes the story from its spatial confinement in the cinema and from the temporal constraints of its weekly screening schedule. Belonging to the club and wearing the thunder riders' mask for play extends the children's engagement with the serial throughout the week and allows the serial to become part of a club member's life-world outside of the local film theater (cf. chapter 3 of this volume). In its pressbook suggestion to form thunder riders' clubs, the serial's marketing performs an aspect of what The Phantom Empire envisions on a broader scale: a story that unfolds around the viewer, during the week, enwrapping audiences in their daily lives instead of solely immersing them once every seven days. In offering related brand content across multiple media platforms, media convergence not only ensures that a producer can reach consumers no matter what their momentary medium of choice may be. In addition, the viewers' awareness that a particular content or franchise is available on numerous platforms suggests that they are surrounded by it. Instead of going out of their way to find a story, the story already is where viewers are. As content unfolds in multiple media at the same time, it moreover seems to exist presently and continuously, readily available whenever consumers decide to access it. It is this sense of liveness, of the unfolding of a story the end of which is not yet determined, that THE PHANTOM EMPIRE gestures towards-with Autry's migration between media, with the serial's diegetic portrayal of convergence, but also in its staging of radio production on film, which enables viewers to watch the radio play being produced as if they were in the studio audience at The National Barn Dance in Chicago.

The PhANTOM EMPIRE continuously negotiates radio and, as I will show, television as well as its own medium, particularly with reference to sound. The serial refuses to allow its mediality or 1930s mass culture to recede into the background. Whereas this presentational mode of storytelling is common among film serials, it also frequently surfaces in other filmic

12 Nevertheless, The Phantom Empire seems not exclusively geared towards children, especially since Gene Autry was popular among women who were the core audience of his WLS morning show Conqueror Record Time (Stanfield 2002: 73). 
forms, for instance series Westerns. Instead of focusing on characterization and the creation of an enclosed story world, 'the series western celebrated performance as an act of value in and of itself' (Stanfield 2002: 100). In this context, Stanfield assigns films featuring Autry a special status in contrast to other films with singing cowboys:

Rather than integrating musical performance seamlessly—as spontaneous singalong around the campfire, as unobserved and private moment, or as serenade to a sweetheart on a ranch house porch-Autry's films frame it explicitly as musical performance. [...] musical performance in singing westerns is a commonplace act that calls attention to the social bond between the entertainer and his audience. [...] The strategies that Autry's films use to secure this contract are diverse: trading on the public performance opportunities of the traveling show or the barn dance; dismantling the distance between professional music artist and amateur film character in the "spontaneous" performance in bunkhouse or parlor; and using recording/radio technologies as narrative conceits that collapse, rather than uphold, audience distinctions between film character, radio performer, and recording artist. (p. 102)

Stanfield bases these observations on the Republic features in which Autry appeared immediately after The PhAntom EmpIRE. Without aiming to suggest that the series Western's performative strategy originated in film serials, Stanfield's analysis attests to the fact that studio-era Hollywood offered multiple modes of address, both in independent productions as well as in films from the majors-musicals, for instance. The form of the film serial lends itself particularly well to a presentational mode of address and a performative appeal, because the breaks and disruptions of a serials' installments as well as their incorporations of technological attractions and stunts already forfeit the more immersive experiences offered by more readily representational film. Serials could thus easily accommodate the mode of address that accompanied Autry from his radio show and The National Barn Dance ${ }^{13}$ to The Phantom Empire and eventually to the features he made at Republic.

13 The National Barn Dance was a show performed for a live audience in Chicago and broadcast for rural audiences throughout the Midwest and parts of the South. It focused on country music (itself a cultural blend of European American and African American styles, including ragtime and blues, but self-stylizing as rural or urban white music) and themes, but also added other styles, such as polka, Hawaiian guitar music, and ballroom dance orchestration. It combined music with comedy, sometimes with drama or children's stories (which Malcolm Claire performed in 
The Phantom Empire takes the presentational variety format to an extreme, in that many of the serial's cast members are themselves attractions. In addition to the musical performances by Autry and his band, the serial features the comedy acts of Oscar (Lester 'Smiley' Burnett) and Pete (William Moore). Smiley Burnett was a comedian and a musician, who picked up on blackface minstrelsy, jazz, black and white rural music styles, and often appeared in drag acts — which he also does in The PHANTom EMPIRE (Stanfield 2002:116-19). ${ }^{14}$ Joke sequences with Oscar and Pete appear in both the broadcast from Radio Ranch and in the serial's general story, extending the variety format from the diegetic broadcast to the serial itself (episode 2, 'The Thunder Riders', and episode 4, 'Phantom Broadcast'). The child protagonists in the serial are played by Frankie Darro and Betsy King Ross (as Frankie and Betsy Baxter). At the time, Darro was a successful actor for both serials and major studio features, and King Ross was a famed child stunt rider (Silver Screen). Together, the two supply much of the serial's stunt action. All of these actors appear in the serial's diegetic broadcast that, in combining a drama serial, comedy acts, and music, brackets the most prominent radio forms of the time. In the mid-1930s, drama and comedy were the most frequently broadcast forms, replacing the music-based programs of the preceding decade. Among the predominant nighttime entertainments were live variety shows, 'a format that combined either one male host or a male-female team with an ensemble of supporting characters, music (usually with an in-house orchestra or singing group), guest stars, comic dialogue, and comedy/drama sketches, with varying degrees of emphasis on these components according to the talents of the host(s)' (Hilmes 1997: 183). Autry's diegetic two-p.m. broadcast combined the most popular radio forms of the time, presenting a fictional, daytime version of the variety show. ${ }^{15}$

blackface), narrated by a show host (Berry 2008: 4-13). The show combines a visual appeal for the studio audience with an address to the radio listeners. A record of a 1942 rebroadcast for the WWII service men is available on youtube; rare video footage from The National Barn Dance is included in the 2011 PBS documentary The Hayloft Gang: The Story of The National Barn Dance. 14 Autry embodies cultural borrowing and montage just as much as the film serial does, particularly The PhAntom EMPIRE. Autry's engagement in cultural borrowing in a sense culminates in the fourth and in the final episodes of THe PнANTOM EMPIRE, when he performs a song yodeling. Tyrolean troupes touring in the United States had brought yodeling to vaudeville in the nineteenth century, from which it was adapted to college glee clubs and blackface minstrelsy. By the 1920s, it had changed in tone by the incorporation of blue notes, and was thus called 'blue yodeling'. Gene Autry picked up on this style in his music recordings of the late 1920s (Stanfield 2002: 63-65).

15 Radio's variety format is itself borrowed from vaudeville and silent cinema. One of the earliest 'radio personalities' was showman Samuel 'Roxy' Rothafel, who was the manager of 


\section{Radio and Film Sound}

The PhANTOM EMPIRE's incorporation of a diegetic radio show effects a tour de force across multiple modes of address and devices of storytelling. Many of these already appear in the serial's initial minutes. The first episode begins in medias res, with a supposed 'raid' taking place in front of Radio Ranch. Autry and his band, on horseback, plunder a wagon full of musical instruments. Picking up the equipment, they set up before a microphone and Autry declares to an implied radio audience that they are 'making another raid on your time', which introduces the diegetic broadcast. For comic effect, this turn of events retrospectively identifies the supposed narrative exposition of the serial's action plot as the beginning of Autry's radio show. His turn to the microphone abruptly terminates the representational mode of storytelling and forces viewers to reconsider their earlier assumptions about the plot. The radio broadcast thus initiated includes - in chronological order-Autry and his band performing a song called 'Uncle Noah's Ark', Frankie and Betsy's invitation of the children in the audience to join the 'National Thunder Riders Club' and visit Radio Ranch, Frankie's and Betsy's narration of the founding moment of the club, Autry's offer to send out sewing patterns for thunder rider costumes to interested juvenile radio listeners, and a narrative radio serial beginning with yesterday's recap and ending in a cliffhanger (episode 1 , 'The Singing Cowboy'). ${ }^{16}$

In these initial eight minutes, the episode shifts through multiple modes of address and pits these against each other. Each of the discernible elements functions as an anecdote with its own mode of narration and viewer address. The succession of anecdotes forces viewers to continuously reconsider their hypotheses about and relationship to the ongoing story, and thereby inadvertently points to the ruptures between the anecdotes. The song and various direct addresses of the radio audience, filmed mostly with a steady frame that foregrounds the radio microphone, are radically presentational and non-immersive. When Betsy and Frankie narrate the founding moment of their thunder riders club, they first appear at the microphone and then a dissolve leads to a flashback sequence that depicts the action as narrated

Capital Theater in New York City where he showed feature films but also directed a vaudeville program. Starting in 1922, his radio show aired live from the theater and was first named The Capitol Theater Gang, later Roxy and his Gang (Hilmes 1997: 60-63).

16 To clarify, this montage of elements does not directly resemble The National Barn Dance, which would have focused much more on musical acts and did not include, as far as I know, a narrative serial or a children's club. However, information on the $N B D$ 's program is comparatively scarce. 


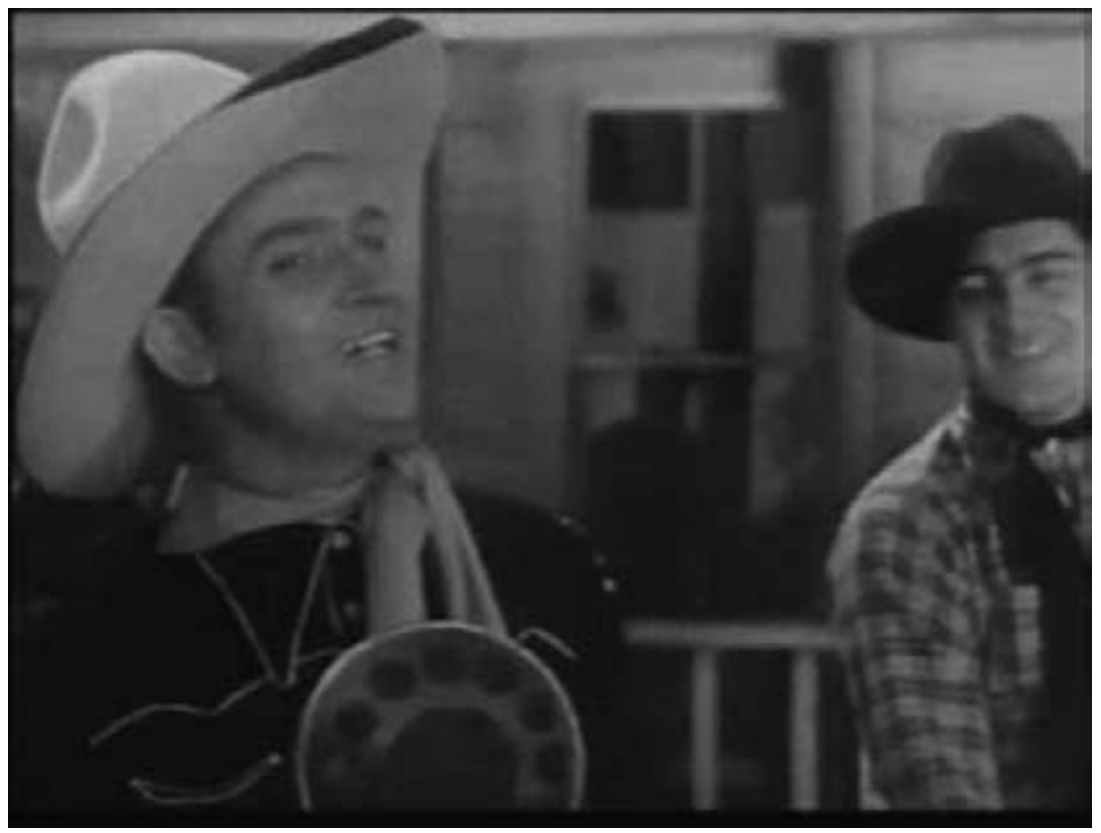

26. Autry sings 'Uncle Noah's Ark' for the radio broadcast (The Phantom EmpIRE, episode 1, 'The Singing Cowboy').

by the kids. When their voiceover stops, a roughly thirty-second stretch of representational filmic narration follows, in which Queen Tika's mounted troops are in pursuit of the children, whose subsequent escape features elaborate horse stunts. Frankie then ends the flashback as he faces the camera and explains: 'and that's how we came to call our club the thunder riders' (episode 1, 'The Singing Cowboy'). In these instances, the viewer address gradually changes from a narrative radio show, via voice-over explanation, to immersive storytelling, which ends abruptly when Frankie turns to the camera. In this instance, the serial points to the similarities and differences of radio and cinematic storytelling and their respective modes of address, and it highlights the possibility of merging them by means of voice-overs, in which the film's frames function as illustrations of the radio story. In such moments, the serial in fact reverses the historical timeline of film development, for whereas cinema in the late 1920s added recorded sound to its previously 'silent' images, the images corresponding to THE PhANTOM EMPIRE's diegetic radio show appear to accompany the sounds of radio. Simultaneously, the serial, by recourse to radio, recreates the sense of liveness that in the silent era resulted from the live musical accompaniment in local theaters. Whereas sound film as a fully recorded medium loses this 
sense of liveness, the broadcast from Radio Ranch highlights the live aspect of radio and recreates it, diegetically, on screen.

Although radio was technologically capable of playing recorded material, which early broadcasters frequently had done, by the 1930s quality radio - especially the variety show — was considered a live form. This association of radio with liveness results mostly from 1920 legislation. In 1922, the allocation policies for radio licensing divided stations into two groups: amateurs and broadcasters. The former were now forbidden to air information or entertainment, including weather and market reports, news, speeches, concerts, and particularly music - a restriction that catered to self-proclaimed advocates of 'high culture' and their criticism of the amateur broadcasters' tendency to play jazz records. As the newly licensed commercial stations similarly neglected their supposed agenda of cultural uplift, a further category of so-called 'Class B' stations was introduced. These stations were prohibited to play phonograph records or use player pianos, restricting them essentially to live entertainment (Hilmes 1997: 48-50). The fact that 'Class B' stations were the most successful broadcasters fed into the increasing public opinion that 'live is better than recorded'. By the time the ban on playing recorded material was dropped in the early 1930s, these stations had firmly established their dominant positions (p. 50). Throughout this period, in the late 1920 and early 1930s, radio was offering increasingly less music and more comedy and drama, which was typically supplied by agencies who represented individual advertisers. In the late 1920 s, these agencies pushed for the allowance of recorded shows, called 'transcriptions', because by shipping programs on phonograph records they could avoid network costs and were able to broadcast shows through multiple regional stations to rural audiences (p. 113, 119). ${ }^{17}$ Nevertheless, the advertising agencies also profited from the networks' access to a nationwide audience, and their productions kept live network transmission the dominant radio form in the United States' throughout the 1930s (p. 127).

Released in 1935, The Phantom EmpIRE references radio exclusively as a live medium. The serial does so by borrowing its variety format from nighttime radio shows that were typically aired live and integrating its drama and comedy serial into that framework. The dramaturgy of the serial's plot hinges on this idea of liveness, as Autry's need to return to Radio Ranch for his two o'clock broadcast constitutes a central anchoring point in each episode. It enables a melodramatic negotiation of 'in the nick of time'

17 The popular comedy sketch series Amos ' $n$ ' Andy, for instance, was recorded since 1928 (Hilmes 1997: 86). 
versus a possible 'too late', and it simultaneously foregrounds the presentist approach to storytelling that casts everything as taking place 'now'.

The sense of liveness created in THE PHANTOM EMPIRE also results from an openly showcased use of sound, as the serial simultaneously visualizes the creation of radio sounds usually produced without filmic documentation and the audio special effects of film that mid-1930s motion pictures also did not habitually capture on screen. THE PHANTOM EMPIRE foregrounds sound in ways that studio-era features often abandoned in favor of an enthusiastic embrace of film sound's capacity to increase the 'realism' of cinematic representation (Spadoni 2007:6). By contrast, the introductory sequence of The PhANTOM EMPIRE quite directly expresses its agenda of showing how radio shows are created: Frankie Baxter invites his radio audience and-via a direct address resulting from him continuously facing the camera- the film audience to visit Radio Ranch and 'see a radio broadcast put on like it should be. Ridin', ropin', real horses, real guns, real cowboys' (episode 1, 'The Singing Cowboy'). Whereas the diegetic radio listeners come in person, the film audience 'visits' the ranch by watching the film.

The ranch setting is a fictional production site for an equally fictional radio broadcast. However, these initial minutes indeed showcase more legitimate aspects of sound production. When Autry's band performs 'Uncle Noah's Ark', a recurring refrain in the song consists of a changing array of animal sounds. ${ }^{18}$ The accompanying frames first show band members create the animal sounds, with the exception of one duck in the beginning. Towards the end of the song, the frames show the animals matching each sound. The film thereby exemplifies how humans dub animal sounds on radio and, possibly, on film. A similar staging of sound production occurs later in the broadcast. When the thunder riders rush to the rescue in the diegetic radio serial, the film shows a stage hand shaking a thunder sheet, that is, a scrap of thin metal mounted on a wooden frame that is used to create the sound of rolling thunder. This shot similarly depicts sound production, and it highlights film's capacity to suggest certain sounds by connecting them to an image. The film thus pinpoints the deceptive possibilities of sound production and the suggestive power of montage. Thunder sheets were by no means new at the time, but were an established percussive instrument used in theater as well as for the accompaniment of silent films. A 1910 column in The Film Index provides a list of 'the most important traps and effects' for the 'smaller exhibitors that are willing to spend a little money', which

18 The incorporation of animal sounds into music was a stock part of sentimental Western music and by no means unique to Gene Autry (cf. Stanfield 2002: 59). 
includes the thunder sheet among twenty-seven other items. The column's author Clyde Martin stresses that these items should be used behind the screen, out of view. ${ }^{19}$ By placing sound production at the center of attention, The Phantom EMPIRE pinpoints the mechanical aspect of filmmaking and thus feeds into the film's operational aesthetic, and it highlights that the mechanics behind the sounds of radio and film are related. Moreover, it demystifies the previously invisible aspects of sound production, which corresponds to Frankie's promise to show a 'real' broadcast production. The serial thus proposes an operational realism instead of a representational one. And in the process, it relocates radio and film sound, which might air from anywhere and be recorded anywhere, in America's heartland and thereby casts modernity's technological feats as the hands-on labor of cowboys.

Another demonstration of sound production follows in episode four, 'Phantom Broadcast', in which the location from which Autry airs his broadcasts changes from the courtyard of Radio Ranch to Frankie's secret laboratory. Previously, the evil capitalist archaeologists trying to remove Autry from the ranch in order to profit from its underground radium deposits framed Autry for the murder of his business partner, the father of Frankie and Betsy. Wanted by the sheriff, the country star is unable to appear for his show and Frankie suggests broadcasting from his hayloft laboratory instead. As Autry performs his song, Frankie and Betsy supply the sound effects in a scene that demonstrates the use of coconut halves to imitate the sound of hooves and the benefits of a duck call. Meanwhile, Autry's band, who has been anxiously waiting for his return in time for his broadcast, listens in with surprise as they hear his remote contribution to the show. This turn of events profoundly changes the relation between performer and audience as well as the nature of the broadcast. Whereas earlier broadcasts were directed at an implied community of listeners, the band and crew on Radio Ranch now function as an audience that is visually depicted on screen, whereas Autry's fictitious larger audience moves out of focus.

Meanwhile, the ruthless archaeologists track the origin of Autry's broadcast by following the wire to the barn. This tracking mirrors Frankie's initial discovery of the underground world of Murania by means of his self-built 'direction finder' - a mechanism to locate the origin of radio transmission - that is reintroduced in this episode. The aim to trace the origin of a broadcast, in connection with Frankie's partially self-built mobile

19 Although admitting that 'the use of a thunder sheet is very seldom called for', Martin details how to use it most effectively_in concert with a roll on the crash cymbal to highlight lightning during a thunderstorm (Martin). 
equipment and his interest in tinkering with radio transmission, evokes a discourse about amateur broadcasting that existed prominently after World War I and into the 1920s. Whereas commercial radio is directed towards an implied community of listeners, amateurs often aimed to identify their communication partners, although these two sides constitute no strict binary opposition. As early as 1906, when anecdotal evidence suggests one of history's many 'firsts' - in this case the Christmas Eve transmission of a combination of speech and music to ships on sea near Massachusetts—radio was envisioned as enabling both point-to-point communication as well as broadcasts to a wider audience (Hilmes 1997:34-37). The beginning of the first World War then placed the control of airwaves into the hands of the Navy and, eventually, of a small number of businesses. ${ }^{20}$ By this time, amateur broadcasters had organized themselves into nationwide clubs, with their own visions for the future of the medium (p. 38). Although government representatives advocated for the amateurs at the 1922 radio conference and recommended that airspace be cleared for them, the new organization of the conference simultaneously removed the amateur organizations from the more important debates. Additionally, government agencies were unable to prevent monopoly formation, which suppressed amateur activity, despite controlling the allocation of airwaves, because the wiring of local stations into national networks depended on the land lines that were owned by the American Telephone and Telegraph Company (Hilmes 1990: 16-18). And whereas AT\&T allowed the smaller CBS to air nationally alongside AT\&T's own NBC stations out of a fear of antimonopoly legislation (Hilmes 1990: 20), amateurs were now pushed 'to the margins of the field they had once dominated', that is, general broadcasting (Hilmes 1997: 41). ${ }^{21}$

Before being largely silenced, amateurs had frequently engaged in 'DXing' or 'fishing in the ether': they tracked the locations of radios that picked up their signals, aiming for the most distant connections possible. Amateur broadcasters did so by repeating their call letters and locations, plus additional technical specificities, and waiting for signal recipients to answer. QST, the journal of the American Radio Relay League, featured a

20 Before WWI, radio was the technology of inventors and entrepreneurs. During the war, the Navy took over the regulation of frequency assignments, pooled patents, and developed the technology. In 1919, the Radio Corporation of America was founded, essentially a merger of corporate business and federal government interests who determined the radio regulations at the time and ended low-key entrepreneurship (Hilmes 1990: 12-15).

21 For the sake of clarity, these remarks simplify the distinction of commercial station and amateurs, considering amateurs as those organized in the amateur clubs. Nevertheless, many amateurs also worked technical jobs, for example for AT\&T. 
prominent section titled 'How Far Can You Hear?' to track and compare these distances via the data sent in by their readers (Hilmes 1997: 42-43). ${ }^{22}$ In The Phantom Empire, Frankie shows a similar interest in finding out where a signal originates and, since the Muranians encode their messages so that to Frankie they simply sound like static, he builds the 'direction finder' to satisfy his curiosity. The archaeologists similarly trace a broadcast, though in a more simplistic manner, when they track a wire to find Frankie's secret laboratory. Whereas Frankie's interest is innocent and juvenile, the archaeologists have less noble pursuits in mind in their aim to find Autry. Thus, instead of pitting amateur broadcasts against a commercial use of radio, the serial pits both of them against the commercial interests behind the archaeologists' search for natural resources. In fact, in the hayloft barn, amateur radio transmission comes to the rescue of Autry's public broadcast.

The Phantom Empire thus models its multiple constructions of what radio is or could be based on contemporaneous and past appropriations of the medium. However, the serial's idea of amateur broadcasting itself refers back to a stereotype of amateur broadcasters rather than to actual historical precedence. Political regulators as well as a more general public, through newspaper reports, constructed a discursive image of amateur broadcasters as young, white, middle-class boys — despite the presence of female, black, and working-class broadcasters. These boys were either considered young heroes who used their scientific skills rescuing ships at sea or helping with the war effort, or they were scorned for disrupting transmissions, causing interference, or distributing false information. When amateurs were in fact mature adults efficiently organized in associations who lobbied against commercial interests at radio conferences, public discourse framed them as chaotic boys running havoc on the ether. This stereotype was only practical for corporations who aimed to exploit radio commercially, who now appeared as the earnest and rational agency willing to regulate the airwaves. According to Michele Hilmes, the exclusion of the amateurs 'from the dominant representation points to the need to "control" this phenomenon discursively in a way that least threatened established social hierarchies. Radio communication, by means of this construction and not by accurate reflection of real conditions, became understood as "naturally" the province of white middle-class boys' (Hilmes 1997: 38-41). In the character of Frankie Baxter,

22 According to Hilmes, these amateurs got bored and therefore started playing instruments or recorded music. They began to air regularly, and QST printed the schedules for these part-amateur, part-commercial shows. As legislation differentiated the two more clearly, QST went back to covering only amateur activity (Hilmes 1997: 40-50). 
The Phantom Empire literalizes this stereotype of a white middle-class boy who plays with radio transmission. On the one hand, this characterization works just as well as it did fifteen years earlier: Frankie's playful activities on the ether present no threat to Autry's more earnest commercial broadcast, and he is the boy hero as his efforts help to identify the underground city of Murania. In fact, Frankie's insistence that his laboratory is secret comes across as boyish foolery because there seems to be no imminent threat and Autry, as the surrogate father figure, can enter the secret laboratory without further ado. Nevertheless, by reintroducing the figure of the amateur radio operator, THE PHANTOM EMPIRE reactivates a historical road not taken; it creates an anecdote ${ }^{23}$ that itself performs an act of media archaeology (cf. Huhtamo \& Parikka 2011). The serial reinstates an alternative appropriation of radio technology that was ruled out in the wake of radio's commercial streamlining. Pointing to this alternative use of radio technology, the serial challenges the model of a commercial, national medium of mass address with which viewers in the mid-1930s were most familiar.

\section{Television}

Whereas Gene Autry and Frankie Baxter embody the commercial broadcaster and the radio amateur, respectively, Queen Tika and her underground kingdom of Murania use media for defense purposes. Murania's control room includes radio technology but it more particularly foregrounds television as a means to coordinate the operations of the underground kingdom's military operations. Although Tika gives orders to her army of thunder riders via portable radios that connect to their watches, her more frequent means of communication and surveillance is television. Her control room, the technological heart of Murania, boasts a large, round, table-top television screen by means of which Tika monitors her empire and the surface world, with no need for a camera device on site. In 1935, that is, before television sets were widely distributed for domestic use, THE PHANTOM EMPIRE showcased the televisual technology in the military context that throughout history has repeatedly furthered the development of media technologies.

The spread of television as a mass medium began in the mid-1930s, following radio with considerable delay (Uricchio 2008: 294). However, the

23 This appropriation of radio technology is an anecdote, as this kind of point-to-point communication and testing of radio mechanisms similarly occurs in other serials, for instance in ACE Drummond. 
large-scale dissemination of television sets throughout the United States ensued only after World War II. As Cynthia Miller points out, The Phantom EMPIRE featured television at a time when only about four hundred television sets existed throughout the United States, four years before the $1939 \mathrm{New}$ York World's Fair that inaugurated commercial TV broadcasting (2009: 67). Nevertheless, the medium's discursive construction and its future constitution were fixed well before, but the Great Depression and the war delayed the spread of the material apparatuses (Castleman \& Podrazik 2003: 8, 15-21). The Phantom Empire appeared at a time that, according to Philip Sewell, marked the end of the negotiation of television's technological and cultural character. From 1935 until the advent of digital technologies, television was 'electronically scanned and analog encoded', and it was understood as airing unidirectional broadcasts from centralized broadcasting stations, with adherence to visual standards borrowed from cinema (Sewell 2014:44). The preceding years, especially 1928-1933, constituted a 'moment of foreclosure of possible futures for television, defining certain uses, content, and social relations as not television' (p.19). Television thus conceptually consolidated as a mass medium a full decade before large parts of the population accessed it. ${ }^{24}$

This solidification entailed the ruling out of technological functions that had been connected to the idea of the televisual since the 1870 s. Newspaper and magazine articles from the nineteenth and early twentieth centuries conceptualized television interchangeably in relation to the telephone, to radio, and to film. In William Uricchio's terms, television was a medium that 'was variously understood as domestic like radio, public like film, or person-to-person like the telephone; that was live and recorded, high definition (more than two thousand lines) and low, large screen and small' (2008: 289). Rather than coinciding with the moment of invention or inception, the release of The PHANTOM EMPIRE co-occurs with the abandonment of a variety of tentative inventions, technological discourses, and futuristic dreams. Similar to its depiction of radio, the serial revisits multiple options of the televisual just as they were beginning to stop being options. At the same time, The Phantom Empire embraces qualities of the televisual that would continue to be part of the medium's discursive construction-most importantly television's capacity to transmit live images.

24 According to Philip Sewell, the delay in the commercialization was endorsed by electronics manufacturers and broadcasters such as RCA, NBC, and eventually RKO and GE because they profited from radio and considered TV a threat; because they feared that a prematurely sold, inferior television would cause a public distaste for the medium; and because they were waiting to have their own technologies patented (2014: 37). 


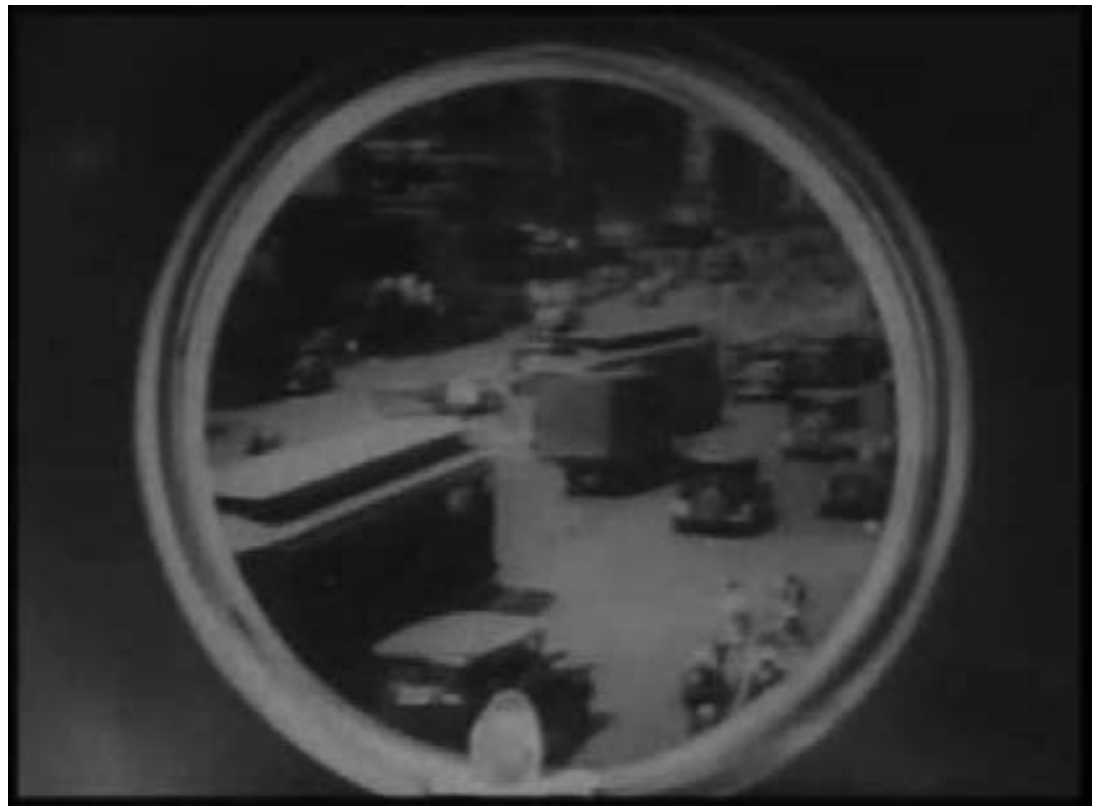

27. Queen Tika's television screen showing a surface world street during rush hour (THE PHANTOM EmpIRE, episode 1, 'The Singing Cowboy').

The underground kingdom of Murania is home to an advanced society that relegates physical labor to robots and practices complete withdrawal from the 'surface world' in the face of its violence, speed, and mechanized chaos. By means of her television technology, Queen Tika ensures the strict and orderly organization of the Muranian empire and its inhabitants by conducting surveillance of Murania and the surface world, which the serial stresses in its insistence that she does not depend on reports from her army of thunder riders. Murania's technological control room is a multi-story factory hall full of gears and levers that-like the underground queendom as a whole — resembles the aesthetics of Fritz Lang's Metropolis (1927).

In the first episode, an operator starts the unnamed televisual apparatus with its horizontal table-top screen. Initially, Queen Tika sees a shot of a street scene with cars, street trolleys, and pedestrians, and she explains that 'the surface people are always in a hurry'. Additional footage provides further proof that the world is 'a madhouse', showing sequences from a horse race, a boxing match (Queen Tika titles it 'death, suffering'), and a car accident occurring on a race track (Tika says 'speed, accidents'; episode 1, 'The Singing Cowboy'). Tika's voiceover descriptions of the televisual images may present 
a joke that foregrounds the fact that the isolated, secluded existence of the Muranians results from their misinterpretation of the action in the surface world. Nevertheless, the moving images shown on her television do portray accident and chaos. However much the serial advertises Murania as an advanced society, Tika experiences urban modernity and its entertainment industries very much in terms of shock and the threat of 'hyperstimulus' and 'neurasthenia' that constituted the modernity discourse of previous decades (cf. Singer 2001: 59-100).

On a self-reflexive level, this instance exposes the serial's use of library footage and its capacity to change that footage by means of editing and the addition or alteration of sound. Simultaneously, the sequence exemplifies the freedom to switch radio or TV channels. In fact, Tika's thunder riders wear 'television dials' around their wrists, and the serial's pressbook offered a cardboard version of these for distribution in local cinemas. Children in the audience could thus pretend to switch the television channels or to place a call. ${ }^{25}$ Paradoxically, the sequence in the first episode highlights the possibility of changing channels in the context of Tika's discontent with its downside, that is, with the failure to find the right channel. Unhappy with the pictures she sees, the queen asks the operator: 'Do I have to witness this insane material because you are unable to find the garden of life?' The image then quickly switches to her requested setting, the surface entrance to Murania, and, with reference to sound technologies, Tika requests 'Sound! I want to hear them' (episode 1, 'The Singing Cowboy'). This sudden discontent with the silent image casts film sound as something audiences asked for, as a completion of cinema's reality illusion.

Queen Tika employs television in a variety of situations that chart multiple visions of what television could be or could have been. Some of these emerge from the diegetic technologies themselves and from the ways in which characters use them, others result from editing. In addition to the surveillance television, Murania's control room features a second television set that is used for direct communication with the guards at the secret entrance to the underground empire. Due to the upright position of the screen, this second TV resembles both a non-diegetic TV set and television apparatuses as they appear in other film serials. ${ }^{26}$

25 The warrior's wrist bands are only shown once in the serial, and the warriors rather use them for radio communication. In fact, the ad in the pressbook calls them 'television dials', although its headline refers to 'radio wrist bands'.

26 For instance, in The Amazing Exploits of the Clutching Hand (Weiss, 1936), Drums of Fu MANCHU (Republic, 1940), or in Spy SMASHER (Republic, 1942). 
Nevertheless, as we learn later on, the larger surveillance television can also be used for communication. In episode six, 'Disaster from the Skies', Autry is on the run from Tika's helpers in the underground kingdom after he was captured and received a death sentence. He sneaks into the control room and holds the engineer at gunpoint, forcing him to contact Frankie and Betsy on the television. The children are in Frankie's hayloft laboratory, intercepting encrypted radio messages from Murania. Autry can see them on the television screen, but the children fail to understand his words. The reason, however, is not the unidirectional nature of television but the fact that Murania's ‘wireless telephone' encrypts communication by means of its 'word scrambler' technology, which makes spoken words sound like static. Autry eventually unplugs and re-plugs various chords until the children can hear him on their radio.

This sequence casts television as an audiovisual technology that interconnects with the wireless telephone in Murania's control room. ${ }^{27}$ The control room thus contains a literal television 'set' (cf. Sewell 2014: 41), a modular apparatus that consists of a connected array of radio, telephone, and screen technologies. Such an idea of composite technologies informed TV discourses until the late 1920s. Discussing the coverage of television in Radio News, Sewell points out that as late as 1927, many writers imagined TV 'as a device that would be separate from the sound unit, as a component rather than an integrated audiovisual box' (p. 41). THE PHANTOM EMPIRE adopts this notion of a modular constitution of television in its narrative when Autry uses the Muranian television to contact Frankie's radio and thereby casts the TV screen as an addition to the radio apparatus. Moreover, the serial portrays the separation of TV's visual and sound components in its set design when it locates the sound equipment, including the 'word scrambler', against a wall in the control room, whereas the television screen is located at its center.

A similar integration of multiple notions of the televisual results from the serial's editing. In the second episode, Queen Tika again skips through various channels when she monitors the surface world, this time showing tanks at war, Wall Street, and police motorcycles. She orders the operator to 'bring in Radio Ranch, the childish amusement played for surface man', just in time for the serial in Autry's daily broadcast. Tika tunes in to daytime drama at a time when such radio serials for female audiences drew substantial listeners, but were also scorned for their sensationalism and immorality (Hilmes 1997: 124). In this instance, the serial connects the otherwise icy, composed, but nevertheless sympathetic leader to a 
stereotype of femininity and afternoon entertainment. ${ }^{28}$ Nevertheless, Tika also scorns the show, resulting in a pun on cultural hierarchies and criticism of radio programming.

As the diegetic broadcast begins, the camera zooms in on Radio Ranch, allowing the audience to watch Autry's story unfold without the added circular frame of Tika's TV screen. When the father of Frankie and Betsy dies in what was intended to be a staged shooting for the radio serial, we witness Autry's escape (he is framed for the murder), thus transitioning from the play-within-the-play to the action in the surface world before returning-zoom out - to Queen Tika's viewing position at her television screen. Through Tika's surveillance perspective, the serial seamlessly proceeds from the play-within-the-play to the overall plot of the serial. The resulting effacement of a distinction between fiction and fact within the filmic world mirrors television's connection of fictional entertainment and live 'reality', for instance in news formats, a combination that already informed radio programming. ${ }^{29}$ Moreover, because this instance relocates the diegetic radio drama to the television screen, THE PHANTOM EMPIRE connects the serialized commercial radio program to the newer mass medium. It describes the travelling of forms between media, bearing witness to the conceptual consolidation of television in terms of 'radio broadcasting, from which it carried over not only its economic, regulatory, and institutional structures but also its familiar program forms, even to specific shows and personalities' (Hilmes 1997: xiv-xv). Therefore, in between its staging of television as a means of communication and surveillance, THE PHANTOM EMPIRE also acknowledges television's soon-to-be-fact status as a conveyor of mass entertainment.

The serial's gesture towards commercial television does not, however, assign a hierarchy of television over radio. Instead of forecasting a replacement of radio by TV, Tika's visual tuning-in to the radio station inaugurates a moment of simulcasting, that is, of the transmittance of video images to

28 A few sequences in the serial point to a rather overt reflection of gender stereotypes. In the first episode, Betsy insists that girls are invited to join their thunder riders club as much as boys are-against Frankie's initial reservations ('The Singing Cowboy'). In episode nine, Frankie and Betsy are brought to Murania and meet Queen Tika, who says 'so, you are the sprout from which surface people spring' and Betsy explains 'I'm a girl' before Frankie adds 'and I'm no sprout!' ('Prisoner of the Ray'). The inclusion of Betsy in the cast was probably a means to attract girls to watch the often boy-oriented sound serials.

29 Such a blurring of lines between fact and fiction was famously taken to an extreme three years later, when Orson Welles' 'The War of the Worlds' aired on CBS' The Mercury Theater on the Air in 1938. In The Phantom Empire, however, this blurring of lines takes place within the diegetic world of the serial. 
accompany a radio broadcast. In the early 1930s, commercially successful television was imagined as tapping into rather than competing with popular radio shows. Focusing on the Chicago-based experimental television channel W9XAP, Sewell explains that it provided a sight broadcast corresponding to the sounds of WMAQ, the commercial radio station of the Chicago Daily News. The project eventually ended because the Federal Radio Commission refused to license commercial TV at the time, allowing W9XAP to exclusively air video for WMAQ's sustaining programs, which had a much smaller following (Sewell 2014: 42-43). The PhANTOM EMPIRE points to this idea of a convergence of television and radio broadcasting when Tika tunes in to Autry's show. Therefore, rather than arriving at a definitive construction of a televisual apparatus, The PнAnтом EMPIRE highlights the interconnection of technologies and the multiple and shifty options of their use, considering media as modular rather than self-contained. By then omitting editorial clues that would reveal the distinction between Autry's broadcast and his pursuit on the prairie, the episode integrates the surveillance function of Tika's TV within this array of televisual use options. In line with its reinstatement of the contingent uses of radio, THE PHANTOM EMPIRE pinpoints the various options offered by television at a moment in history in which this contingency was being curtailed. The serial identifies media archaeological roads not taken, precisely when the definition of television in terms of a 'better' radio gradually suppressed other models of the medium's use (Uricchio 2008: 300).

According to Sewell, the impact of scientific management in the 1920 and early 1930 contributed to the definition of television as a consumer good (2014: 24). Leaving the field of technological progress only to scientifically trained personnel, scientific management 'ultimately narrowed the range of technical practices' (p. 26). At the time, imagery and writing in the Scientific American implied 'that there is a singular correct answer to the "problem of television", and this notion would become crucial in regulatory demands for standardization. Thus, television would be the logical and unique end of the correct application of scientific theory and engineering practice' (p. 26). In this view, management is first and foremost the mastering of contingency and the reduction of options. Film serials, by contrast, revel in the exposition of options. Before the sound era, serials had already engaged in the management of modernity's increasing contingency by aligning options side-by-side, by juxtaposing them without a tendency to reduce (cf. Brasch \& Mayer 2016). The PHANTOM EMPIRE applies this mode of storytelling to its self-reflexive engagement with media change. When public discourse had more or less agreed on a particular view and future of television, the serial 
turns back and realigns the possible notions of television and radio as they could have come into place. The serial manages these notions by arranging and contrasting them without placing one hierarchically above the other, refusing to take part in the ruling out of options and possibilities. This is not nostalgia for lost prospects or discourses. The serial rather realigns all options in the present, casting them as non-extinct rather than bygone-engaging in perpetual management rather than an eventual reduction of contingency. The one hierarchy that does result from this alignment of options is one that places the film serial itself above all other media and forms, as the one medium that can embrace and assemble the other media uses, forms, and modes of address. The serial struggles, however, with an integration of the other media's capacity to transmit live content.

\section{Liveness and The Phantom EmpIRE's Construction of Cinema}

As I have shown, The PhAntom EMPIRE arrives at discursive constructions of radio and television that actualize the array of their possible uses rather than understanding them solely as unidirectional media of mass address. In its portrayal of a number of radio and televisual forms, the serial ascertains its own capacity to take up the contingent forms of these media. When Queen Tika tunes in to Autry's radio show and watches his broadcast through her surveillance television, for instance, the resulting simulcast is a connection of two technologies enabling an audiovisual experience that film serials offer as well. The serial thus acts as a medium that can accommodate and combine the forms of other media, and it thereby increases its own array of options. The following passages first show how the serial's appropriation of options of other media also lays bare which options the serial as a medium fails to offer. In a second step, I will return to a consideration of the film serial as a form and I will trace the implications of its tendency to actualize multiple contingencies - that is, to act as a medium - for its status as one form of the medium of sound film.

As addressed earlier, some of the contingent options of media emerge discursively as markers of quality, and for radio and television, liveness appears to be such a marker. However, liveness is one option within the metaphorical pools of possibilities labeled 'television' and 'radio' that does not appear in the pool of 'sound film'. And yet The PHANTOM EMPIRE highlights liveness in a way that exhibits its own lack of the trait, seemingly aiming to extend its own horizon of contingent options beyond those offered by sound film. Mascot's serial particularly foregrounds television's capacity to transmit live 
images when it employs a live broadcast to resolve its murder plot. Since episode two, Autry had been wanted for the murder of his partner on the ranch, Frankie's and Betsy's father. However, the singing cowboy as well as the audience are aware that the greedy scientist Prof. Beetson is accountable for the murder. In the serial's final episode, Autry confronts Beetson with the accusation, who readily admits to the murder and claims that he could not be proven guilty anyhow. Autry responds saying 'I think you're wrong there, partner. That is, if Frankie learned anything about television down in Murania' (episode 12, 'The End of Murania'). The camera zooms out and reveals the cinematic image to be in fact diegetically mediated by television, and both the children and the Sheriff are watching Beetson's confession (in the prairie, with no cameras around) on a screen in Frankie's hayloft laboratory. The editing of this sequence again demonstrates the serial's ability to subsume the televisual image, the latter of which is simultaneously cast as omnipresent and as live, as opposed to recorded. When the camera zooms out, viewers realize that we witnessed not only the recorded instance in the film serial, but the live television transmission together with Frankie, Betsy, and the Sheriff. By means of television, the final episode retrospectively attributes to its own mediated image a character of quasi-liveness despite its status as recorded film. In other words, The PнAntom EMPIRE seeks to recreate a sense of liveness as much as its medium and form of 'canned' film allows.

The discourse on television continued to debate a differentiation between live and recorded material, in which liveness remained a quality marker even when it was technologically possible to broadcast recorded programs. In a 1927 article in Radio Broadcast, Carl Dreher proposed that we differentiate between permanently recorded media aiming to overcome time and media of simultaneity that defeat distinctions of space (Sewell 2014: 34-35). Similarly, Hugo Gernsback, editor of Radio News in the mid-1920s, insisted on the distinction of television and 'radio movies', the latter describing the transmittance of pre-recorded and scanned film, which Gernsback aimed to exclude from the televisual discourse (p. 23). ${ }^{30}$ This focus on live transmission bears evidence of aims to locate the new medium in relation to radio but also to delineate it from film, its moving image predecessor. Rather than emerging as an alternative and possible replacement of cinema, critics such as Gernsback tended towards a definition of television that would highlight its advantages over cinema's higher resolution pictures. According

30 For a more detailed take on Gernsback's influence in the development of radio, see Massie and Perry (2002). 
to Sewell, 'by the 1920s, in the United States, film had staked out its identity and the relative high ground in an aesthetic media hierarchy. Consequently, arguments about good television would be skewed toward liveness and ability to capture the real rather than beautiful or poetic expression' (p. 34). However, the supposed high-cultural status of cinema never included film serials, which existed on the low-brow fringes of studio-era film production. As television staked its ground in contrast to the existing norms of cinema, it highlighted features that film serials similarly aimed to incorporate. In The PhAntom EMPIRE, these notions of liveness and a non-representational realism appear when Frankie addresses his radio and film audience and promises to show 'a radio broadcast put on like it should be. Ridin', ropin', real horses, real guns, real cowboys' (episode 1, 'The Singing Cowboy').

However, television's celebration of liveness is not solely a reaction to its inability to rival the quality of cinematic moving images. In fact, the notion of liveness had been a part of the television discourse even before the dissemination of film in the late nineteenth century. As Uricchio explains,

inspired by the telephone, early notions of the televisual assumed that moving pictures would be seen simultaneously with their production, that is, that the medium would serve as something like an electronic camera obscura, or telescope, bringing spatially distant services into direct visual proximity with the viewer. From 1876 onward, a well-developed notion of television as a 'live' moving-picture medium offered a counterpart to the 'stored' moving images seen, for example, with Reynaud's projecting praxinoscope, Edison's kinetoscope, and eventually, in 1895, with what we today celebrate as projected moving pictures. (2008: 288)

In the nineteenth century, television was imagined as a live medium and the emergence of film was in these regards disappointing. In fact, Uricchio argues that films of the medium's first decade - street scenes, or shots filmed from the fronts of moving trains, for instance - worked with a selfascribed claim of liveness, as 'the films' arrangements of time and space potentially simulated a televisual viewing experience in the same manner that the panorama simulated the experience of the panopticon' (p. 296). The terminology used to describe early film forms and technologies similarly references markers of liveness, as the terms 'actuality' but also 'bioscope' or 'vitagraph' illustrate (pp. 296-297). According to Uricchio, around 1903 cinema saw the transition from actualities to recorded drama, from 'seemingly live to the emphatically stored' (p. 296). The self-ascribed live form nevertheless continued to exist, overtly in newsreels or sing-alongs, but 
also in the self-ascribed liveness of film serials. The PhAntom EMPIRE addresses its audience in a presentational mode that, by subsuming radio's and television's forms, mimics a live performance.

Recording, both in radio and on television, is never an option in THE Phantom Empire. As a quality program, the two p.m. broadcast from Radio Ranch naturally airs live. Whereas the serial negates radio's capacity to air recorded material and thus transcend time, it stresses radio's surpassing of space when Autry contributes to his show from Frankie's laboratory (episode 4, 'Phantom Broadcast') or from an airplane (episode 8, 'Jaws of Jeopardy'). Both times, Autry tunes in in real-time, because the recording of his songs would sidestep the deadline dramaturgy that accounts for the suspenseful climax. The serial thus foregrounds liveness in addition to the presentism already apparent in film serials in general, which always include qualities of simultaneity and presence because of the accommodation of recurring installments into the viewers' weekly routines, and because of their film style and cinematography, which highlight presence and simultaneity in parallel editing, fast-paced action, and storytelling in the present tense..$^{31}$ The presentation of live forms within the film serial underlines this presentist mode of storytelling, which aligns everything taking place within the narrative world as taking place 'now'. Paradoxically, The PнANTOM EMPIRE accentuates direct address and a focus on simultaneity by emphasizing these qualities with reference to radio and TV, while simultaneously acknowledging that these 'new media' can accommodate live action much better than the film serial could.

As it has been addressed, media only become visible through their forms, which are concretizations of a choice of options from the larger contingency offered by the medium. By taking up and arranging forms that are borrowed from radio and television, film serials act as media and increase their own contingency. However, the differentiation of medium and form is a working distinction in so far as both medium and form are temporary and arbitrary attributions. That is, we can assign either status to the film serial for the matter of analysis (cf. Krämer 1998: 56o-561). Thus, although serials act as media, they are also quite consciously a form within the medium of sound film. And as forms, serials are not live but recorded, even if the fact of

31 Note that recaps seemingly tell us 'what happened last week' and cliffhanger endings often highlight 'what will happen next week?' as a question instead of admitting to the fact that it is rather about 'what the film tells you next week, but what has already been shot and canned'. For a more detailed take on the presentist and presentational qualities of film serials, see chapter three of this volume. 
their recording aims to surpass space (shipping the film to theaters across the nation) rather than time (recording for the archive). However, in the particular case of THE PHANTOM EMPIRE, the shift from serial-as-medium to serial-as-form is not only an analytical ascription; the serial itself performs this shift. Whenever the serial introduces a borrowed form, that is, when we hear Autry's radio show or when we watch the proceedings through Queen Tika's television, The PhAnтom EmpIRE acts as a medium. In the remaining, more immediately mediated scenes, the serial acts as a form. The former allows us to abstract the film serial (medium) from the radio broadcast or surveillance television image (as forms); the latter enables the abstraction of sound film (medium) from the film serial (form).

In Luhmann's theory, medium and form reciprocally effect and determine each other. The individual options of a medium couple and decouple - that is, forms concretize and disintegrate, and media are momentarily bound and released again. This process, in which the differentiation of medium and form continuously reproduces itself, takes place over time and it circulates (Luhmann 1997: 199). Sybille Krämer highlights this process when she stresses that Luhmann's theory casts form as a 'time-consuming execution', an 'operation situated in time and space', which is 'performative', 'temporary, unstable', and 'fleeting' (1998: 559, 565-566; my translation). By casting the film serial interchangeably as a medium and as a form, The РнANTOM EMPIRE effectively showcases this continuous reciprocity on screen. It thus makes visible the operations that shape the film serial as medium and as form, that is, it portrays its own continuous becoming. In a sense, the experience of watching this reciprocity unfold over time on screen is the operational aesthetic in its purest form: the appreciation of process as portrayed not by means of a medium, but the process of the medium itself. Luhmann compares the reciprocity of medium and form to a von Neumann probe: a machine that autonomously produces replicas of itself (p. 199). The serial is a self-propelling, self-perpetuating machine, and it allows us to watch it work.

A similarly self-reflexive approach to storytelling informs the serial's ending. The Phantom EMPIRE's final-episode climax culminates in the eventual destruction of the underground kingdom of Murania. In a civil war between Queen Tika and Muranian revolutionary forces, the 'disintegrating ray' destroys the underground empire that it was designed to protect. Cinematographically, the destruction of Murania is effected by means of exposing large print stills of the Muranian set to heat until the chemical emulsion melts and bleeds downwards (Miller 2009: 68). The result is the obliteration not only of the Muranian Empire in the serial but of the 
film's material substance. Despite its pragmatic reliance on film stock, the serial-as-a-medium thus casts its material substance as one contingent option among many. Importantly, the serial does not end at this point. Instead, Prof. Beetson's televised confession follows afterwards, enabled by a piece of equipment that Frankie saved from Murania, which allows him to complete his self-built television on Radio Ranch (episode 12, 'The End of Murania'). The serial thus destroys the vulnerable, tangible materiality of film, but it nevertheless continues to exist, with a scene that capitalizes on the liveness of television.

Esposito describes the relation of medium and form-like Luhmann and Krämer - in terms of oral and written language. Written language detaches communication and its observation: 'The observer is distinguished from the object of observation, which enables new forms of reflexivity-including the potential to observe oneself as an observer and to communicate about communication' (Esposito 2004: 13). According to this logic, film serials can reflect on and observe liveness particularly because they are not a live form themselves. In this way, when The PнAnTom EMPIRE capitalizes on the forms of radio and television, it always simultaneously benefits from its own cinematic medium that enables the serial to bracket all of these other forms. The film serial as a recorded form that acts as a medium emerges as a manager of other forms, which enables the serial to juxtapose and engage reflexively with the forms of the American media landscape of the $1930 \mathrm{~s}$ and 1940s. In this context, THE PHANTOM EMPIRE's continuation of its story after it showcased the physical destruction of film on film highlights its self-reflexive tendency and it demonstrates the film serial's paradoxical ability to record liveness.

\section{Beyond The Phantom EmpIRe: Redirecting Filmic Storytelling via Radio and TV}

Although The Phantom EMPIRE's joyride across various forms stands unrivaled in the history of film serials, other serials also embraced the multiplicity of media and forms of their time. They, too, act as media that display and manage contingency. As the following passages will show, serials such as The VAnishing Legion (Mascot, 1931), ACE Drummond (Universal, 1936), and RADIO PATROL (Universal, 1937) not only portray various applications of radio technology, they also use radio to manage or rein in their chaotically meandering plots. Similarly, THE AMAZING EXPLOITS of The Clutching Hand (Weiss, 1936) and Spy SMASher (Republic, 1942) 
showcase television in ways that at times jump-start an otherwise stagnating narrative. These serials showcase radio and television as a means to exercise the control and surveillance of policemen, villains, and city spaces more generally, and they negotiate the advantages and possible threats of such technological dragnets.

The Vanishing Legion, Ace Drummond, and Radio Patrol manage multiple forms or use options of radio, but within these stories, radio also serves to manage motifs, stock plots and characters, and similar short elements. The pool of options from which serials compose individual episodes includes not only the forms of other media but also more concrete story elements. The remainder of this chapter will consider both the forms of radio and TV and individual motifs, stock plots and characters, and reappropriable incidents or props as anecdotes. These anecdotes are unpolished and unrefined in the sense that they do not have an identifiable beginning or end. They are not complete in and of themselves, and although they can be readily integrated into a serial, they are never sutured seamlessly into an ongoing film. Anecdotes always stand out, they can always be identified as something that occurs similarly in other episodes, other serials, or other stories. Just as The PhANTOM EMPIRE's Radio Ranch drama serial is a form that is taken from radio, ACE DRUMMOND's yellowface villain is taken from pulp fiction and similarly occurs in a multitude of films and serials: both of them stand out as borrowed. ${ }^{32}$

The first three serials that serve as examples make use of radio to install diegetic managers within their stories, that is, an agent who directs plot developments and organizes anecdotal elements as the serial proceeds. Afterwards, a closer look at THE AMAZING Exploits OF THE CLUTCHING HAND and SPY SMASHER, both of which showcase multiple appropriations of television, will reveal how technological advancement threatens to enable complete surveillance. While making use of television to organize their plots and connect individual anecdotes, these serials also lay bare an increasing mid-twentieth-century unease in the face of a possible governmental appropriation of these technologies for control and, in the case of SPY SMASHER, the rise of fascism.

Universal's 1937 serial RADIO PATrol begins with a sequence that outlines the advantages of radio connectivity. After a series of shots and superimposed newspaper headlines that show a frantic and inefficient police force, a local official suggests the establishment of a 'radio squad', that is, a squad of police

32 The introduction of this volume offers a more detailed definition of anecdotes; for a description of the importance and effect of repetition and reiteration in film serials, see chapter five. 
cars connected by two-way radios that combine into a 'patrol system that blankets the city, night and day' (episode 1, 'A Million Dollar Murder'). The following episodes set out to demonstrate the efficient use of the radios, which allow police headquarters to disperse information among all cars, but which also enable individual policemen to call for assistance. Episode three, for example, skips a chance for an obligatory car chase when the protagonist officer Pat O'Hara (Grant Withers) broadcasts the license number of a suspect's car to the entire squad ('Flaming Death'). In the following episode, O'Hara calls for assistance before entering the master villain's hideout, and police headquarters uses the radio system to locate the serial's female and kid sidekicks (Kay Hughes as Molly Selkirk and Mickey Rentschler as Pinky Adams) after they borrow O'Hara's squad car (episode 4, 'The Human Clue'). Radio technology puts police cars on the map, allowing headquarters to monitor their whereabouts and send assistance if necessary.

Conversely, radio dragnets can also serve to coordinate the criminal activities of a master villain and his gang. THE VANISHING LEGION (Mascot, 1931), for instance, narrates the hunt for a villain called 'the Voice', who organizes his group of criminals by means of small pocket radios and thereby avoids appearing in person until he is identified in the final episode. ${ }^{33}$ Pocket radios, stationary radio receivers, and telephones combine into an information network that the Voice uses to give orders to his henchmen-and specifically not, as we learn in the penultimate episode, to hear their reports. Like Queen Tika in The Phantom EmpIRe, the Voice does not depend on reports because he is omniscient (episode 11, 'Capsule of Oblivion'). Thus, whereas the police squad employs a democratic version of two-way radio communication in RADIO PATROL, the master villain of THE VANishing LEgION insists on the unidirectional character of his transmissions or literal 'narrowcasts'.

ACE Drummond (Universal, 1936), by contrast, juxtaposes these two uses of radio in a struggle over its application in aviation. The serial's eponymous protagonist (John King) is called to a Mongolian airport under construction to fight a master criminal called 'the Dragon' in his attempts to thwart the airport's development. Whereas the airfield crew needs radio to communicate with approaching aircrafts, the Dragon transmits high voltage to kill the pilots. Additionally, the Dragon controls his followers in ways that resemble THE VANisHing LEGION's chief malefactor: he transmits orders to his men via radio-wired 'prayer wheels', spinning fans, rotating airplane propellers, and a turning water wheel. Drummond's aim throughout the 
serial is to end the Dragon's one-way transmissions of spoken word and high voltage in order to secure the radio network for airport communication.

All three of these serials expose concerted networks of radio communication as highly vulnerable, and neither hero nor villain ever fully controls them..$^{34}$ The serials emphasize this vulnerability in scenes in which a character takes advantage of the nonvisual radio apparatus and impersonates the master villain. Each serial appropriates this anecdote in a short micro-plot that spans one or two episodes. The leading lady (Edwina Booth as Caroline Hall) of THE VANishing Legion, for example, poses as the master villain the Voice without any of his henchmen being able to tell the difference. Two years into the production of sound serials, this instance casts technologically transmitted voices as interchangeable, which may also be understood as a comment on the quality of early sound in a film that was still advertised as an 'all-talking serial'. 35 Similar anecdotes of technologically enabled impersonation recur in other serials. ACE DRUMMOND appropriates the motif in episode eleven, when a minor character pretends to be the Dragon, who at this point in the story controls the radio communication on and around the Mongolian airfield. ${ }^{36}$ The attempt fails: the Dragon first exposes the impersonator in a widely disseminated radio message, and when the latter escapes in a small plane, the master villain murders him by transmitting high voltage through the aircraft radio (episode 11, 'The Dragon Commands').

Radio Patrol reenacts a similar anecdote twice, but in line with the serial's stressing of radio-enabled police efficiency, the impersonations take place over the phone. First, a murder suspect pretends to be the dubious steel mill owner Harrison (Gordon Hart) and the deceit remains undetected (episode 6, 'The House of Terror'). Two episodes later, police detective O'Hara calls the same steel mill owner, now posing as a private

34 RADIO PATROL, for instance, presents a variety of interceptions beginning in episode six, when both the criminal agents based in the Egyptian quarter and the workers at Harrison's steel mill listen in on police communication (episode 6, 'The House of Terror'; episode 7 , 'Claws of Steel'). In later episodes, the criminal parties also wire-tap each other, without either of them using radio communication: Harrison's men listen in on the Cairo Café in the Egyptian quarter via telephone (episode 9, 'Plaything of Disaster'), and the Iranian representative Mr. Tahata (Frank Lackteen) listens in on Harrison's calls by placing one of his tools, disguised as a cigarette vendor, near a telephone pole, tapping the wire (episode 10, 'A Bargain with Death'). 35 According to the pressbook for The VAnishing Legion. Another reference to sound appears in episode six, when a car driver cannot understand Happy Cardigan (Harry Carey) because the car's engine is too loud ('The Radio Riddle').

$3^{6}$ This control is foregrounded when Drummond disposes of his airplane's radio technology before take-off to ensure an unharmed flight in the same episode (episode 11, 'The Dragon Commands'). 
detective in Harrison's employ. This time, Harrison suspects and remarks: 'Your voice sounds different'. ${ }^{37}$ However, Harrison's suspicion has no overt narrative effect because the police officer manages to convince him of his assumed identity. Yet the instance exposes the serial's repeated use of the anecdote. This self-reflexive recognition may even point to its outdatedness, as the first sound films were by this time almost a decade old and the initial technological difficulties had mostly been resolved.

Such correspondences within individual serials and across numerous serials result from but also expose their nature as montages of anecdotes. None of these serials copy from or imitate each other. Instead, they all draw ideas from and contribute to the formation of a larger popular-cultural sourcebook, transforming narrative elements into distinguishable anecdotes that recur repeatedly and varyingly across large numbers of serials. This use of anecdotes is a strategy to effect seriality's more general correlation of repetition and variation (cf. Eco 1985; Kelleter 2012a). At the same time, the repeated occurrence of an element within serials disables its seamless integration into the narrative and exposes its anecdotal character. In short, repetition and anecdotes reciprocally determine each other's existence. The repeated appropriation of the same anecdote in RADIO PATROL, for instance, effects the serial's self-conscious acknowledgment of repetition when the steel mill owner suspects being tricked and simultaneously establishes the moment as anecdotal. In fact, RADIO PATROL also expresses an awareness of the repetition of anecdotes across different serials when Officer O'Hara, in response to realizing that a radio dispatch from police headquarters must have been intercepted, predicts that 'someday they're gonna code our broadcasts' (episode 5, 'The Flash of Doom'). Up to this point in the serial, radio dispatches had never been intercepted, yet the threat is familiar enough from other serials or films for O'Hara's reaction to seem adequate.

In their refusal to fully integrate into a narrative, anecdotes point to the conditions of storytelling. The serials' use of a large quantity of anecdotal elements in fact feeds into their presentational narratives and mode of address. Serials capitalize on a process that Ruth Mayer describes for the cross-media recurrence of Fu Manchu, the prototypical Asian arch villain who sparked the appearance of later criminal figures such as the Dragon: recurring 'figures, character constellations, and themes' - and, I would add, anecdotes more generally-'allow for a focus on the "ornamentation of the sets", the circumstances and conditions of narration and representation,

37 This instance of reenactment is similar to the first episode of the 1921 serial THE HOPE DiAmOND MYSTERY, which is detailed in chapter five of this volume. 
which otherwise tend to be neglected in favor of the plot's "foreground" action' (2014: 97). In other words, anecdotes shift the audience's attention from the 'what' to the 'how' of cinematic narration, to the particularities of framing, editing, mise-en-scène, and to a film's operational aesthetic. As the preceding examples illustrated, the juxtaposition of established and alternative uses of media often takes place through a serial's appropriation of anecdotal elements, such as the presence of radio-empowered master villains or stories of intercepted messages and radio-enabled imposture.

Such a correlation - that is, a scene in which a serial adapts an anecdotal micro-plot and demonstrates multiple forms of radio-occurs prominently in Ace Drummond. In episode four, Ace Drummond and his sidekick Jerry (Noah Beery Jr.) confiscate one of the villain's radio-wired prayer wheels and take it back to the airfield. In this scene, the serial actualizes a plot that occurs similarly in THE VANISHING LEGION, for instance, when the county sheriff takes possession of a small pocket radio and tunes in to the dispatches of 'the Voice (episode 4, 'The Radio Riddle'). ${ }^{38}$ Ace Drummond, however, presents a rather open version of the idea, as the protagonists remain in possession of the prayer wheel and the Dragon only notices the loss and terminates his dispatches eight episodes later (episodes 4 and 12, 'The Radio Riddle' and 'The Squadron of Death'). In the meantime, Drummond, his love interest Peggy (Jean Rogers), the airport mechanic Jerry, and the kid sidekick Billy (Jackie Morrow) test the prayer wheel in a lengthy passage that details the functions of the mechanism.

In the sequence in which the protagonists test the prayer wheel, ACE DRUMMOND revels in the appeals of its featured fictional technology (episode 4, 'The Radio Riddle'). The prayer wheels, through which the master villain often transmits his orders, benefit from a combination of visual spectacle and narrative/technological process. Prayer wheels are both technological marvels and lavish ornaments, 'blurring the distinction between magic and technology, orientalism and modernity' (Mayer 2014: 98). Placing these

38 In this scene in ThE VANISHING Legion, the villain issues the remote-controlled explosion of the pocket radio, thus taking up a story element that ACE DRUMMOND, with its radio-transmitted murders, reiterates throughout the serial. Generally, the villains of these two serials are very similar, which also surfaces in the similarly formulaic endings of their dispatches: whereas the Voice ends each transmission saying 'the Voice has spoken', the Dragon adds 'the Dragon commands' to each of his messages. Both of these phrases are stylized versions of the similarly formulaic radio communication standards in military and civilian air traffic. The importance of such 'aviation phrases', as the pressbook for ACE Drummond calls them, surfaces in the pressbook's suggestion to place a model airplane with a hidden microphone in the lobby and to have an announcer repeat phrases such as 'Calling Ace Drummond' or 'Visibility: Good'. 
contraptions at the center of its narrative and of episode four in particular, ACE Drummond 'spin[s] off speculations on the techniques and technologies of communication', as Mayer describes it for techno-orientalist serials and features of the 1930s in general and Fu Manchu narratives in particular (p. 97). Like the surrounding anecdote, the design of the prayer wheel borrows elements that circulate extensively in other serials, films, or cultural texts more generally. For ACE DRUMMOND, the prayer wheel becomes an attraction which, according to the serial's pressbook, should function as a centerpiece of local cinema lobby decorations. The pressbook includes a drawn model of the prayer wheel and it encourages local theater managers to build one, install a two-way microphone, and connect it to their office to enable communication with visitors in the lobby. Such a set-up would have allowed local patrons to study the apparatus like Drummond and his companion do in the serial. The pressbook's suggestion thus underlines the prayer wheel's status as a prominent attraction in the serial and would have enabled film viewers to reenact versions of the prayer wheel test in the serial, transforming the filmic anecdote into a cultural motif to be appropriated outside of the cinema.

The test of the prayer wheel in ACE DRUMmond displays the forms and functions of radio and deconstructs its mythic character in the serial. The full implication of this test comes to the fore when we not only think of serials as assembling and managing anecdotes, but if we apply an anecdotal approach to their analysis. As the following pages will outline, the prayer wheel test in ACE DRUMmond resembles an 1877 newspaper report of a demonstration of Bell's telephone in its transmission of words and music. ${ }^{39}$ The remarkably similar accounts establish the test sequence itself as an anecdote. The correlation of the scene from the film serial and the nineteenth-century newspaper article shows how such tests not only introduce and explain a new technology but similarly explicate all its possible uses instead of highlighting one application of a technology in particular.

The scene in which ACE DRUMmOND's protagonists test the prayer wheel compares the capacities of the unidirectional radio contraption to the twoway communication enabled by telephony. Jerry highlights the prayer wheel's unidirectional transmissions early on, when he describes it as 'some kind of radio receiving system' (episode 4, 'The Radio Riddle'). When Drummond then attempts to transmit a message from the airport radio station to Jerry

39 The introduction provides a more detailed description of the anecdotal approach and its place in New Historicist literary or cultural theory. For further information, also see Gallagher \& Greenblatt (2000) and Maza (2004). 
at the prayer wheel, Peggy and Billy hold phone contact so that Peggy, sitting with Jerry, can report to Billy whether the radio transmission came through. Having thus established the prayer wheel as unidirectional as opposed to radio as used in air traffic, Drummond demonstrates the possible uses of one-way transmissions: he counts to four and then sings his trademark tune 'Give me a Ship and a Song', which he performs repeatedly throughout the serial (episode 4, 'The Radio Riddle'). Far from being simply another occasion for the reenactment of Drummond's musical feature, the sequence reestablishes radio's entertainment function, pointing to a positive side to the technology that the villain hijacks so unscrupulously.

This depiction of the parallel use of radio and the telephone seems to recreate nineteenth-century exhibitions and demonstrations of the latter, a novelty in the 1870 s. When Alexander Graham Bell presented his telephone to a live audience in 1877 in Salem, Massachusetts, he called his assistant in Boston, who transmitted Morse code played on an organ, played a song, and ended with a short speech directed at the Salem audience (Scientific American, 1877).$^{40}$ Bell thus placed the telephone in the context of and in comparison to other media of the time, notably the telegraph, but also the phonograph as referenced by the transmission of music. In 1936, when ACE DRUMMOND unintentionally enacts a comparable instance on the film screen, the telephone was fully established as a means of person-to-person communication - even in film serials that otherwise retrospectively open discourses of media and technology use.

ACE DRUmmond presents a radio test that seems curiously modeled on nineteenth-century telephone demonstrations, exemplifying radio's capacity to transmit spoken language and an entertaining musical performance. In both instances, the demonstration of communication technologies distinguishes the newer technology from its predecessors-telegraphy in Bell's case, telephony in ACE DRUMMOND-and it demonstrates the possible functions of that newer technology, of transmitting for instance code, messages, or entertainment. Now, whereas telephony was truly novel in 1877 , radios were widely disseminated before the release of ACE DRUMMOND, and radio use, as noted earlier, was a discursively fixed category. However, staging the radio test enables the serial to recall the contingent variety of radio uses as if radio was a novelty. ACE DRUMmOND thus actualizes a creative use of radio in its present moment in America in the mid-1930s.

40 This anecdote of the presentation of Bell's telephone is detailed and considered in connection with the operational aesthetic in the nineteenth century in chapter two of this volume. 
Such a reintroduction of alternative uses of media does have a political connotation, especially in the 1930s and 1940s. Mayer assigns to these decades both a 'fascination with Chinese things' and 'an almost obsessive interest in what one could call the functionalization of these things for the purposes of control' (2014: 97). Thus, the prayer wheel in ACE DRUMMOND is not accidentally both a techno-orientalist object of interest and the villain's means to transmit commands and organize the operations of a larger criminal gang. The Dragon's successful control of his henchmen hinges on the containment of his audience: his explicitly unidirectional narrowcasts target a very specific, limited group of listeners. He essentially employs radio as a point-to-multipoint technology, in the sense that his communication reaches more than one listener, but it is not an open, mass-address broadcast. It is this vulnerable middle stage that numerous serial villains like the Dragon or the Voice depend upon and defend.

The villains not only assume this commandeering function within the diegesis, they similarly organize the narrative itself. Often, transmissions from the Voice in THE VANIsHing LEgION, information from police headquarters in RADIO PATROL, or the commands of the Dragon open new strands of action. Whenever the narrative seems to have hit a dead end, a radio transmission points to a new angle, a new scheme, a new way to intervene. Radio technology, it seems, works in concert with the film's camera-eye, allowing police chiefs or master villains to share a visual perspective with the audience and often exceed their knowledge. As unseen governing agents who manage the narrative by providing clues for further action, serial villains are on par with a film's director, that is, they mirror a director's function within the narrative. This director position within the narrative enables the serial to literally come into being as it unfolds on screen, and it allows viewers to witness the creative orchestration of multiple narrative strands and anecdotal elements into a concerted collage over time. In this sense, radio technology opens up a position of power that can be taken up by either governmental agencies or criminal masterminds. This insight curiously informs the ending of ACE DRUMMOND, in which the protagonist's sidekick Jerry first kills the Dragon with the latter's own destructive radio technology and then applies a sledgehammer to the villain's radio system (episode 13, 'The World's Akin'). Killing the master villain is not enough; the technology that enables his power in the first place needs to go as well. This double destruction reveals that the technology itself is just as much a threat as the master villain. Moreover, such a destruction necessarily terminates the serial, as killing the diegetic director and his means to direct disables the actualization of further narrative strands. 
In the second half of the decade and into the 1940s, this governing function of the villain gained intensity. Equipping their master villains with television contraptions, The Amazing Exploits of the Clutching Hand (Weiss, 1936) and SPy SMASHER (Republic, 1942) not only update their narratives to the new or prospect mass medium, they also forcefully demonstrate the threats of these media and their surveillance function when overseen by the wrong authority. The Amazing Exploits of The Clutching Hand (Weiss, 1936) updates the scientific and technological prowess of its protagonist detective Craig Kennedy (Jack Mulhall) and his opponent, the Clutching Hand, both of whom already peopled one of the first popular serials, Pathe's The Exploits of ElAine in 1915. The sound serial takes up the already iconic, fist-clenching criminal and places him at a televisual control switchboard as the manager of a gang whose members can be called up on an oversize screen individually or in different combinations, each according to their individual identification numbers.

Like the Asian arch-villain of ACE Drummond, the Clutching Hand determines the mostly unidirectional use of a medium that is capable of reciprocal communication, and he asserts his discursive and technological power over the medium in actualizations of established anecdotes. In an example that combines what could be called the 'controlled-speech anecdote' and the 'impostor anecdote', one of the Clutching Hand's henchmen uses the television to report the existence of an impostor, but the villain criticizes his inferior's blunt call, telling him to wait until he is being called (episode 6, 'Steps of Doom'). Nevertheless, talking to a larger group of gang members in later episodes, the master villain does require them to voice their understanding of his instructions - affirming his sense of a highly controlled but nevertheless two-way communication system for a limited range of viewers (episodes 11, 'The Ship of Peril'; and 13, 'The Mystic Menace'). Throughout the serial, the Clutching Hand decides who is allowed to speak, which he makes clear earlier in the serial when he refers to a captive (Robert Frazer) who appears on the TV screen, explaining that 'he can hear, he can see, but he cannot talk. As long as I will it, he will remain in that condition' (episode 4, 'The Phantom Car'). Therefore, while taking up anecdotes that other serials similarly use, THE CLUTCHING HAND foregrounds the authoritative rule of its master crook, in speech, visually through his grand television screen, and in the convergence of multiple technologies. The villain's control room enables a connection of fully compatible technologies, such as television and a regular telephone (episode 3, 'House of Mystery'). The connection of technologies allows him to transcend spaces, which the serial exemplifies when the Clutching Hand steers a remote-controlled car via a moving symbol on a 
map that curiously resembles twenty-first-century GPS navigation systems. He lures his pursuers - that is, Detective Kennedy and his sidekick-into a barn and issues its similarly remotely triggered explosion (episodes 4, 'The Phantom Car'; and episode 5, 'The Double Trap'). Throughout its run, the serial combines fictional and nonfictional uses of media and means of media convergence, a showcasing of technological contingency and multiple, typically fruitless attempts at regulation.

The serial's ending, that is, Detective Kennedy's eventual identification of the villain's identity, results from Kennedy's appropriation of television to transcend time instead of space, as the villain does. Whereas the Clutching Hand's television set enables communication with henchmen in different places, Kennedy operates a 'viscatone' in his laboratory: a surveillance television with a recording function. Repeated instances of its use demonstrate its ability to both display action going on elsewhere in real-time and to record moving images for later viewings (episodes 6, 'Steps of Doom'; and 10, 'A Desperate Chance'). Despite the viscatone's recording function, Kennedy employs photography to capture a screen image and resolve the serial's central mystery. In the final episode, the villain's captive Mr. Gironda appears on screen and Kennedy quickly takes a photograph, develops it in his laboratory, and through its study realizes that Gironda and the Clutching Hand are one and the same person (episode 15 , 'The Lone Hand'). ${ }^{41}$ In an instance that casts liveness as a problem rather than as an advantage, Kennedy employs photography to overcome the fleeting nature of the televisual transmission. The serial thus in a sense plays out its fight of good versus evil in terms of the contrast of the material presence of the televisual apparatus and its nevertheless placeless, fleeting transmissions (cf. Denson \& Mayer 2012a: 92). The live character of television that was pivotal to the identification of the murderer in THE PHANTOM EMPIRE now appears as a threat, and recording becomes the means to seize the master criminal. ${ }^{42}$ In both serials, however, power depends on the mastery of the full range of modernity's media.

In a later serial, Republic's SPY SMASHER (1942), the master villain's function as a director both of a villainous gang and of the serial's narrative has

41 The cause of the villain's actions thus turns out to be a combination of greed and insanity. This split-personality theme similarly occurs in ThE ExpLOITS OF ELAINE (Pathe, 1915), where the 'Clutching Hand' turns out to be Elaine's fiancé who appeared throughout most of the earlier episodes. The notion of capturing a televisual image by means of photography reappears curiously in the 1965 film FANTÔMAS SE DÉcHAîNE (Denson \& Mayer 2012a: 95).

42 The Clutching Hand highlights the necessity of recording technologies to collect traces in crime detection in ways that resemble a similar focus on recording in THE Exploits of Elaine, as described in chapter four of this volume. 
a more overtly political connotation. Whereas earlier serials describe a fear of interconnected and hijacked technologies in the hands of criminals, later serials reframe this worry as a fear of totalitarian regimes. SPY SMASHER's hidden criminal 'the Mask' (Hans Schumm) is a Nazi on American soil who controls a communication system that hides behind the façade of the 'Trans-Ocean Television Corporation'. In fact, however, the TV station is a complex surveillance system that connects a switchboard in a TV tower, a submarine, and radio-equipped cars (episodes 5, 'Descending Doom'; and 7, 'Secret Weapon'). Instead of resulting from an inferred convergence with film's camera-eye, the Mask uses an actual diegetic camera to spy on Admiral Corby (Sam Flint), the army contact of SPY SMASHER's eponymous caped superhero (Kane Richmond). Two journalists of the Trans-Ocean Television Corporation repeatedly record interviews with Corby and intercept sensitive information simply by leaving the camera on when they are asked to leave the room, enabling the Mask to follow a live broadcast of Admiral Corby's meetings and phone calls (episodes 2, 'Human Target'; 7, 'Secret Weapon'; and $10,{ }^{2} 2700^{\circ}$ Fahrenheit').

As I have shown, previously released serials highlighted radio's and television's broader ranges of contingency and cast their downsides as a result of the media having been hijacked by sinister forces. In a sense, serials thereby adopt an argument that Bertolt Brecht criticized as early as 1927, when he said that defenders of radio justified its blameworthy results by stressing its full range of use options and thereby cloaking its contemporaneous actualizations (Cohen, Coyle, \& Lewty 2009: 5). Instead of simply arguing that radio's and television's forms could outweigh the negative effects of their current applications, serials stage an actualization of those other options. SPY SMASHER now reverses that argument when it actualizes a darker vision of television, in which technological contingency continues to exist beneath the façade of a discursively fixed, commercial, unidirectional broadcasting system. In this scenario, multiple forms and options of use are a threat rather than a blessing. Accordingly, Spy Smasher operates specifically not by opposing technology with technology and by reinstating television's morally favorable use but as a lone fighter who is neither dependent on radio or television nor part of the army or any other organization. ${ }^{43}$ The caped superhero can therefore track and fight the Mask

43 Curiously, though released in 1942, SPY SMASHER insists that its superhero is not part of the army and can thus act freely, which the army cannot because the United States was not at war with Germany (episode 6, 'The Invisible Witness'). At the time, Marvel's comic heroes had been fighting the Nazis since 1940, and in 1943, Columbia's Batman fought Nazis in a film 
in ways that Admiral Corby cannot, but he lacks a group of comrades, and his access to technology is restricted to the land-line telephone in his apartment. ${ }^{44}$ The hero thus depends on physical combat, but he is also safe from all technological means of spying. As a result, the vast communications system fails to save the masked villain, but its weaknesses remain unexplored. In opposition to the defeat of the master villain and the destruction of his radio technology in ACE Drummond, Spy Smasher defeats the Mask but not his media. The serial simply exhibits technology, demonstrates its functions, and exposes its powers, but it kills off its master operator without destroying the media enabling his operations. The serial exhibits contingency, but it leaves technology's potentially threatening implications in place, creating an implicit job vacancy for other villains to take the Mask's place.

In summary, the 'golden era' of film serials not only coincided with the heyday of radio and the conceptualization of television in terms of a similar broadcast model, serials themselves embraced the resulting multiplicity of forms and modes of viewer or listener address. On the one hand, serials took part in the larger transformation of popular culture that informed the 1930s and 1940s. On the other hand, serials reflected the ongoing changes from silent to sound film, from recorded forms to the option of liveness, from image-based media to radio's nonvisual forms. Particularly a cultural montage like The PhAnTom EMPIRE addressed and capitalized on these shifts, not only by taking up radio and television's forms but also in their coterminous showcasing of the cooperation and integration of various businesses into larger firms and the possibility of media convergence. Moreover, by appropriating not only current forms but previously discarded appropriations of radio and TV, serials exposed the forms of these media as discursive constructs.

Serials were both entangled in this context of media change and they emerged as its managers - in integrating the forms and modes of address of multiple media, serials self-identified as superordinate media that offer viewers a chance to compare and contrast multiple forms within one engaging and thrilling film experience. As a consequence, the serials' own mode of address was continuously being renegotiated. Some serials, as I have shown, employed the police force or a master villain as a diegetic manager

serial (Biesen 2005: 4). Shot just when the US entered the war, SPY SMASHER's stance on the war is surprisingly cautious.

44 His only companion, a Frenchman, sacrifices his life for Spy Smasher in episode six, which Higgins takes as an example of the tendency of film serials to quickly pass over emotionality in favor of action (episode 6, 'The Invisible Witness'; Higgins 2016: 65). 
as a means to integrate the multiple forms and the multiple anecdotes of which individual serials are composed. However, the repetition of both forms and anecdotes assured that they could be identified as forms and anecdotes - serials never sutured or glossed over the ruptures between their multifarious elements. The result is a presentational staging of cultural contingency that cast the cinematic medium as one possible option among many, which forecast the film serial's status as an 'other' within cinema as an institution, which could migrate elsewhere whenever the chance presented itself. It is this curious disassociation from their own institutional context that informed the migration and concurrent demise of film serials at a time when television was successfully disseminated across the United States.

\section{Bibliography}

Ace Drummond. Dir. Ford Beebe and Clifford Smith. Perf. Noah Beery Jr., John King, Jean Rogers. Universal, 1936.

Ace Drummond (Universal, 1936). Pressbook. New York Public Library for the Performing Arts, Dorothy and Lewis. B. Cullman Center.

Amos ' $n$ ' Andy. Perf. Charles Correll, Freeman Gosden. WMAQ, 1928-1943.

Berry, Chad. 2008. "Introduction: Assessing the National Barn Dance." In The Hayloft Gang: The Story of the National Barn Dance, edited by Chad Berry, pp. 1-18. Urbana and Chicago: University of Illinois Press.

Biesen, Sheri Chinen. 2005. Blackout: World War II and the Origins of Film Noir. Baltimore: The Johns Hopkins University Press.

Bolter, Jay David, and Richard Grusin. 1999. Remediation: Understanding New Media. Cambridge, MA: The MIT Press.

Brasch, Ilka, and Ruth Mayer. 2016. "Modernity Management: 1920s Cinema, Mass Culture and the Film Serial." Screen 57 (3).

Castleman, Harry, and Walter J. Podrazik. 2003. Watching TV: Six Decades of American Television. 2nd ed. Syracuse: Syracuse University Press.

Cohen, Debra Rae, Michael Coyle, and Jane Lewty. 2009. "Introduction: Signing On." In Broadcasting Modernism, edited by Debra Rae Cohen, Michael Coyle, and Jane Lewty, pp. 1-7. Gainesville, FL: University Press of Florida.

Denson, Shane, and Ruth Mayer. 2012. "Bildstörung: Serielle Figuren Und Der Fernseher." Zeitschrift Für Medienwissenschaften 7 (2): 90-102.

Drums of Fu Manchu. Dir. William Witney, John English. Perf. Henry Brandon, Robert Kellard, William Royle. Republic, 1940.

Eco, Umberto. 1985. “Innovation and Repetition: Between Modern and Post-Modern Aesthetics." Daedalus 114 (4): 161-84.

Esposito, Elena. 2004. "The Arts of Contingency." Critical Inquiry 31 (1): 7-25.

Everett, Justin, and Jeffrey H. Shanks. 2015. "Introduction: Weird Tales - Discourse Community and Genre Nexus." In The Unique Legacy of Weird Tales: The Evolution of Modern Fantasy and Horror, pp. ix-xix. Lanham, MD, and New York: Rowman \& Littlefield. 
Exhibitor's Trade Review. 1925. "Serial Pictures Will Help to Stabilize Your Attendance - Give Them a Chance," February 14.

Fantômas se déchaîne. Dir. André Hunebelle, Haroun Tazieff. Perf. Mylène Demongeot, Louis de Funès, Jean Marais. Gaumont, 1965.

Gallagher, Catherine, and Stephen Greenblatt. 2000. Practicing New Historicism. Chicago and London: University of Chicago Press.

Higgins, Scott. 2016. Matinee Melodrama: Play and the Art of Formula in the Sound Serial. New Brunswick: Rutgers University Press.

Hilmes, Michele. 1990. Hollywood and Broadcasting: From Radio to Cable. Urbana and Chicago: University of Illinois Press.

—.1997. Radio Voices: American Broadcasting, 1922-1952. Minneapolis: University of Minnesota Press.

Huhtamo, Erkki, and Jussi Parikka. 2011. "Introduction." In Media Archaeology: Approaches, Applications and Implications, edited by Erkki Huhtamo and Jussi Parikka, pp. 1-24. Berkeley and Los Angeles: University of California Press.

Jenkins, Henry. 2006. Convergence Culture: Where Old and New Media Collide. New York: New York University Press.

Jenkins, Henry, Sam Ford, and Joshua Green. 2013. Spreadable Media: Creating Value and Meaning in a Networked Culture. New York: New York University Press.

Jones, Robert Kenneth. 1975. The Shudder Pulps: A History of the Weird Menace Magazines of the 1930s. West Linn, OR: FAX Collector's Editions.

Kelleter, Frank. 2012. "Populäre Serialität: Eine Einführung." In Populäre Serialität: Narration - Evolution - Distinktion: Zum Seriellen Erzählen Seit Dem 19.Jahrhundert, edited by Frank Kelleter, pp. 11-46. Bielefeld: transcript.

Krämer, Sybille. 1998. "Form Als Vollzug Oder: Was Gewinnen Wir Mit Niklas Luhmanns Unterscheidung von Medium Und Form?” Journal for History of Law (Rechtshistorisches Journal) 17: 558-73.

Lenthall, Bruce. 2007. Radio's America: The Great Depression and the Rise of Modern Mass Culture. Chicago: University of Chicago Press.

Luhmann, Niklas. 1997. Die Gesellschaft Der Gesellschaft. Frankfurt am Main: Suhrkamp.

Martin, Clyde. 1910. "Playing the Pictures." The Film Index, December 10.

Massie, Keith, and Stephen D. Perry. 2002. "Hugo Gernsback and Radio Magazines: An Influential Intersection in Broadcast History." Journal of Radio Studies 9 (2): 264-81.

Mayer, Ruth. 2014. Serial Fu Manchu: The Chinese Supervillain and the Spread of Yellow Peril Ideology. Philadelphia: Temple University Press.

Maza, Sarah. 2004. "Stephen Greenblatt, New Historicism, and Cultural History, Or, What We Talk About When We Talk About Interdisciplinarity." Modern Intellectual History 1 (2): 249-65.

McChesney, Robert W. 1993. Telecommunications, Mass Media, and Democracy: The Battle for the Control of U.S. Broadcasting, 1928-1935. Oxford: Oxford University Press.

Metropolis. Dir. Fritz Lang. Perf. Alfred Abel, Gustav Fröhlich, Brigitte Helm. UFA, 1927.

Miller, Cynthia J. 2009. "Defending the Heartland: Technology and the Future in The Phantom Empire (1935)." In Heroes of Film, Comics and American Culture: Essays of Real and Fictional Defenders of Home, edited by Lisa M. DeTora, pp. 61-76. Jefferson, NC: McFarland.

Myers, Henry. 1945. "Weird and Wonderful." The Screen Writer, July.

Radio Patrol. Dir. Ford Beebe and Cliff Smith. Perf. Catherine Hughes, Mickey Rentschler, Grant Withers. Universal, 1937.

Radio Patrol. (Universal, 1937). Pressbook. New York Public Library for the Performing Arts, Dorothy and Lewis. B. Cullman Center. 
Roxy and his Gang. CBS, 1922-1925.

Scientific American. 1877. "More Telephone Triumphs," March 3.

Sewell, Philip W. 2014. Television in the Age of Radio: Modernity, Imagination, and the Making of a Medium. New Brunswick: Rutgers University Press.

Silver Screen. 1937. "Off-Stage Shots," February.

Singer, Ben. 2001. Melodrama and Modernity: Early Sensational Cinema and Its Contexts. New York: Columbia University Press.

Sklar, Robert. 1994. Movie-Made America: A Cultural History of American Movies. New York: Vintage Books.

Sorensen, Leif. n.d. "Weird Tales: The Unique Magazine.” The Pulp Magazines Project. Accessed October 21, 2016.

Spadoni, Robert. 2007. Uncanny Bodies: The Coming of Sound Film and the Origins of the Horror Genre. Los Angeles: University of California Press.

Spy Smasher. Dir. William Witney. Perf. Marguerite Chapman, Sam Flint, Kane Richmond. Republic, 1942 .

Stanfield, Peter. 2002. Horse Opera: The Strange History of the 193os Singing Cowboy. Chicago: University of Illinois Press.

Telotte, J. P. 1999. A Distant Technology: Science Ficiton Film and the Machine Age. Hanover, NH: Wesleyan University Press.

The Amazing Exploits of the Clutching Hand. Dir. Albert Herman. Perf. Rex Lease, Ruth Mix, Jack Mulhall. Weiss, 1936.

The Exploits of Elaine. Dir. Louis J. Gasnier, George B. Seitz, Leopold Wharton, and Theodore Wharton. Perf. Arnold Daly, Creighton Hale, Pearl White. Pathe, 1914-1915.

The Mercury Theater on the Air. Host and Dir. Orson Welles. Perf. Orson Welles, changing cast. CBS, 1938.

The Phantom Empire. Dir. Otto Brower and Breezy Eason. Perf. Gene Autry, Frankie Darro, Betsy King Ross. Mascot, 1935.

The Vanishing Legion. Dir. Ford Beebe and B. Reeves Eason. Perf. Edwina Booth, Harry Carey, Frankie Darro. Mascot, 1931.

Uricchio, William. 2008. “Television's First Seventy-Five Years: The Interpretive Flexibility of a Medium in Transition." In The Oxford Handbook of Film and Media Studies, edited by Robert Kolker, pp. 286-305. Oxford: Oxford University Press.

Wasko, Janet. 1994. Hollywood in the Information Age: Beyond the Silver Screen. Cambridge: Polity. Young, Paul. 2006. The Cinema Dreams Its Rivals: Media Fantasy Films from Radio to the Internet. Minneapolis: University of Minnesota Press. 
